\title{
Hydro-torrential hazard vs. anthropogenic activities along the Seti valley, Kaski, Nepal: Assessment and recommendations from a risk perspective
}

\author{
Narayan Gurung ${ }^{1,2, *}$, Monique Fort ${ }^{1}$, Rainer Bell ${ }^{3}$, Gilles Arnaud-Fassetta ${ }^{1}$, \\ Narayan Raj Maharjan ${ }^{4}$ \\ ${ }^{1}$ Université de Paris, UMR 8586 PRODIG, Paris, France \\ ${ }^{2}$ Kadoorie Agricultural Aid Association, Pokhara, Nepal \\ ${ }^{3}$ Department of Geography, University of Bonn, Germany \\ ${ }^{4}$ Centre for Sustainable Studies, Kathmandu, Nepal \\ *Corresponding author'semail: jyonus@hotmail.com
}

\begin{abstract}
The Seti River originates from the Annapurna Massif in the Higher Himalaya of Nepal and flows through the Pokhara valley in the Lesser Himalaya. The Seti River witnessed a disastrous flash flood on May 5th, 2012 causing the death of 72 people, obliterating dozens of homes and damaging infrastructures worth millions of dollars. Despite the 2012 flood event and several warnings by scientists for more yet bigger scale future floods in the Seti valley, fluvial risk is being aggravated by anthropogenic activities such as unplanned human settlement, encroachment of riverbanks, haphazard construction of road, drinking water, and hydropower projects in potential flood hazard areas in addition to the increased impacts of climate change on geological and hydro-metrological hazards as in other parts of Hindu Kush Himalayan Range. Covering some 40-km distance from the Seti headwater (Sabche Cirque) down to Pokhara city, the study is carried out based on hydro-geomorphological mapping, analysis of land-use and land-cover change, hydrological analysis including HEC-RAS modelling, historical archives, and interviews with local people. The study shows a significant change on the land use and land cover of the Seti catchment, mainly the urban/built-up area, which is increased by 405\% in 24 years period (1996 to 2020 ) and by $47 \%$ in 7 years period (2013 to 2020). Further the study reveals that anthropogenic activities along the Seti valley have increased fluvial risk and are likely to invite more disasters. From the HEC-RAS analysis, two motor bridges built over Seti River were found to have insufficient freeboard to safely pass the highest flood discharge for 100 years return-period. Instead of relocating people to safer places, the government and local authorities rather seem to have encouraged people to live in the floodplain by providing basic amenities such as drinking water, electricity and access road. Given the context of climate change and Pokhara valley and the Seti catchment being in a high-seismic gap zone, there is a strong possibility of similar flood to the scale of 2012 or even greater in Seti River. Though the fluvial risk can be managed in a sustainable way through the application of functional space concept, i.e., by allowing more space (freedom) for rivers, this economic and environment friendly approach of the fluvial risk management has not been implemented yet in the Seti valley nor in Nepal. Rather the encroachment of floodplains by anthropogenic activities along the Seti valley is on an increasing trend. Many settlements and infrastructures along the valley have been identified vulnerable to hydro-torrential hazards, therefore it is utmost necessity to implement functional space river concept, land use and land plan policy, early warning system and public awareness education in order to mitigate and manage the future impact of fluvial hazards along the Seti valley.
\end{abstract}

Keywords: Seti River; Anthropogenic activities; Disaster; Fluvial risk

Received: 30 March, 2021 Received in revised form: 15 June, 2021 Accepted: 16 June, 2021

\section{INTRODUCTION}

A considerable number of infrastructure projects (road, bridges etc.) are damaged or washed away annually by hydro-torrential hazards such as landslides and flood in Nepal (Gurung et al., 2020). From this study, it is intended to give a clear message that given the ecologically fragile mountains in Nepal, unplanned and haphazard infrastructure development and settlement in hazard prone areas will never be sustainable. By respecting nature and consideration of river-flow dynamics, most fluvial disasters can be avoided because disasters begin with human beings as the main cause (Gill and Malamud, 2017). Fluvial risk is the combination of direct or indirect hazards linked to the action of river flows: flood, lateral and/or vertical erosion and sedimentation in the channel and the riverbanks, channel avulsion in the floodplain, edgefalls (bank toppling), and environmental degradation, which impact human and/or structural and/or functional stakeholders and question the vulnerability and resilience of societies (Arnaud-Fassetta et al., 2009). The Seti River (Fig. 1), that drains the Pokhara 
valley (the second largest city of Nepal), experienced a disastrous flood (i.e., hyperconcentrated flow) on May 5, 2012 that surged downstream through the upper Seti gorges, sweeping away 72 people, obliterating dozens of homes and damaging infrastructures worth millions of dollars (Bhandary et al., 2012; Dwivedi and Neupane, 2013; Kargel et al., 2013; NASA, 2013; Kargel et al., 2014; SANDRP, 2014). Studies by Bhandary et al. (2012), Petley and Stark (2012), Hanisch et al. (2013), Kargel et al. (2014), Oi et al. (2014) and Petley (2014) have warned the Seti valley is highly prone to further flooding similar to the scale of May 5, 2012 or, even bigger. In a study, the river side settlements at Ramghat [Fig. 1 (13)] are reported to be prone to 50- and 100-year's return period flood (Basnet and Acharya, 2019). However, it is not studied yet how the hydro-torrential risk is being developed along the Seti River valley, mainly after the 2012 Seti disastrous flood. This study aims at answering the following research questions: (i) How has fluvial risk been developed along the Seti valley? (ii) Are the new motorable bridges built over the Seti River after the 2012 flood safe to high floods? (iii) How have land use and land cover changed in the Seti valley over the years, especially after the 2012 flood? (iv) Why are people living in the floodplain areas? (v) Are the actions taken by the public authorities to reduce flood hazard sufficient and effective? (vi) Is there any possibility of recurrence of a flood similar to the scale of 2012 or greater in the Seti River? (vii) Finally, what could be the best way forward (structural measures versus non-structural measures) to avert possible flood disasters in the Seti valley?

\section{STUDY AREA}

The Seti valley (catchment area: $\sim 586.36 \mathrm{~km}^{2}$ ) originates from the Sabche Cirque $(4500 \mathrm{~m})$, in the Eastern part of the Annapurna Himal ( $8000 \mathrm{~m})$, and traverses through narrow gorges before reaching Pokhara city $(800 \mathrm{~m})$, about $40 \mathrm{~km}$ downstream (Fig. 1). The study is carried out from the Seti gorges outlet to Pokhara city (Fig. 1). Prominent places along the Seti valley that witnessed impacts at different scales during the 2012 Seti flood have been marked from 1 to 14 (Fig. 1). Four places (red dots, Fig. 1) are studied and discussed in detail for their hydrotorrential risk and are analysed further about the role of anthropogenic activities to transform flood hazards into disasters. We selected these four sites because (i) they were affected by flood events in the past, the latest being the May 5, 2012, Seti flash flood, and (ii)

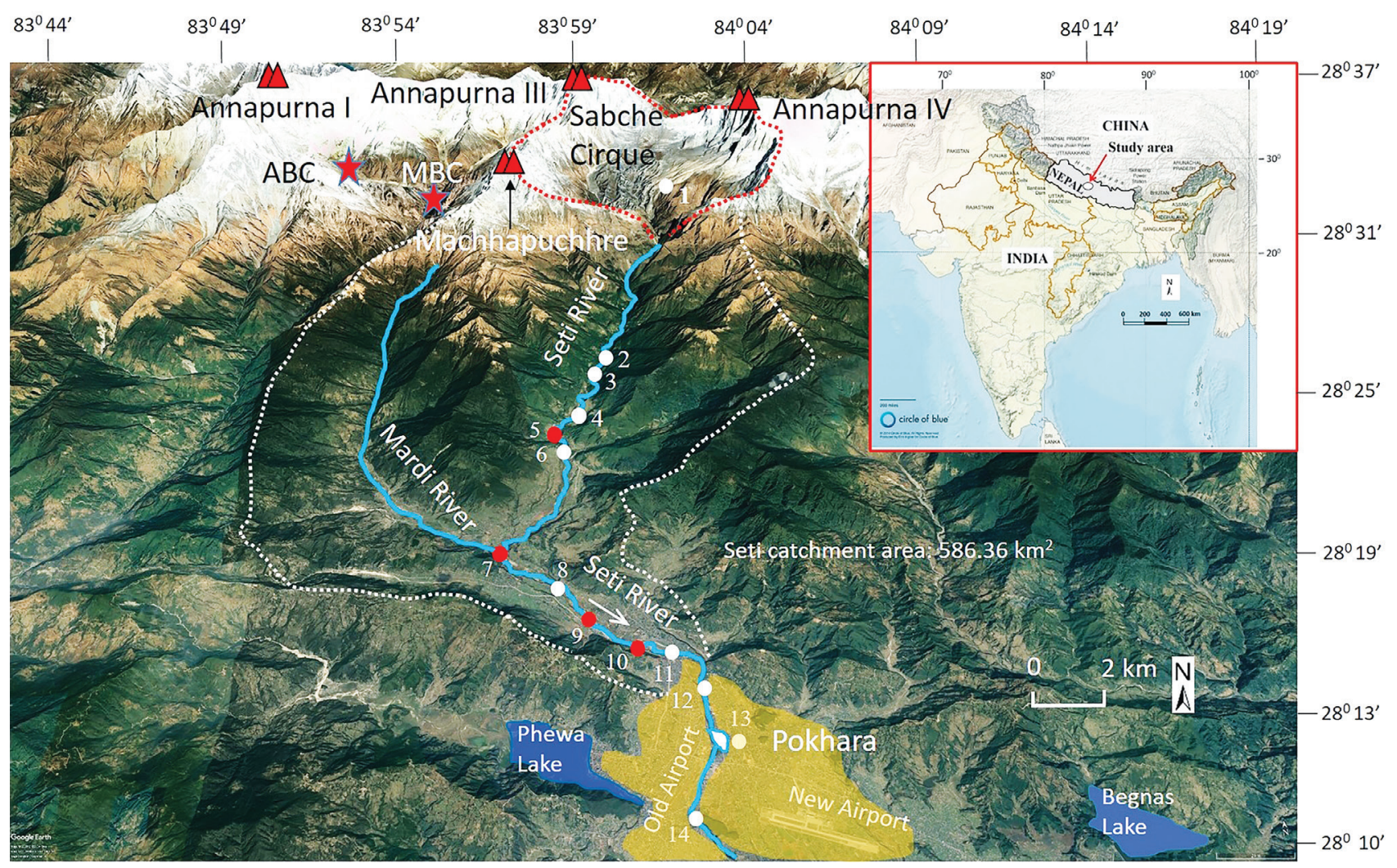

Fig. 1: Seti catchment showing prominent places that are vulnerable to hydro-torrential hazards. Red dots are places discussed in detail in this paper for their hydro-torrential risks. ABC: Annapurna Base Camp; MBC: Machhapuchhre Base Camp. 1: Sabche Cirque; 2: Jimirbaari; 3: Saadal, Ebang and Kapuche; 4: Bharabhuri Bagar; 5: Khaarpaani Tatopani; 6: Seti Mureghat (lies some 3 km downstream from Khaarpaani Tatopani); 7: Mardi Dovan; 8: Hemja Bensi; 9: Masina Bagar, Upallo Gosti and Tallo Gosti; 10: Kaseri Bazzar (Laltin Bazzar) and Shanti Tole; 11: Sukhawati Gumba and KI Singh Bridge; 12: Narayanthan; 13: Ramghat; 14: Ratopahiro (Source: Google Earth, 14 January 2020). 
they consist of dense settlements and infrastructures.

\section{GENERAL GEOMORPHIC HISTORY}

The Seti catchment has very distinctive landforms: a steep mountainous front contrasting with the Pokhara basin (Gurung, 1965, 1970), characterised by a flat morphology, a dramatic set of alluvial terraces, and localised canyons of the Seti River and its tributaries (Fig. 2). The Seti River flows through the deep and narrow section from its headwater at Sabche Cirque (Fig. 3). The morphology of Pokhara valley is the result of different processes generated from the Seti headwater, among which two are particularly prominent. (i) The Ghachok glacio-fluvial conglomerates (composed of all rocks outcropping along the Sabche Cirque cliffs, including the yellowish Larjung limestones; (Colchen et al., 1981), deposition of around 12,000 years ago (Gurung, 1970; Yamanaka et al., 1982; Fort and Freytet, 1983; Fort, 1986, 1987; Koirala and Rimal, 1996; Koirala et al., 1998). (ii) The Pokhara gravels (mostly composed of Nilgiri Limestones, or Sombre Formation; Colchen et al., 1981) were deposited by two or three mega-debrisflow events during the medieval ages (Yamanaka et al., 1982; Fort, 1987; Koirala, 1998; Koirala et al.,1998; Fort, 2010; Schwanghart et al., 2016; Stolle et al., 2017). These mega debris-flows were derived from giant mountain-wall collapses in the West face of Annapurna IV (7525 m), East of Sabche Cirque (Fig. 2 ), and were triggered by mega-earthquakes (Fort, 1986, 1987, 2010; Schwanghart et al., 2016; Stolle et al., 2017). The landforms derived from these two Ghachok and Pokhara Formations are quite different due to their differential resistance to erosion and to their geometric relationship in relation to differential uplift (Hormann, 1974; Yamanaka et al., 1982; Fort, 1987, 2010). North of the valley, the indurated Ghachok Formation (locally called "gaunda") forms an upper terrace bounded by steep cliffs; it was progressively entrenched by the Seti River then abruptly and partly filled by the Pokhara gravels, now forming the lower, most recent terraces sets. In contrast, in the centre of the valley, the Pokhara gravels are superposed upon the Gaunda-Ghachok conglomerates (Hormann, 1974; Fort, 1987, 2010). The Ghachok Formation, intensely lithified due to its high content of calcium carbonate, behaves rather like a rock; this explains (i) the extended karstification, a process which creates wide open cracks and large caves in the sub-ground, and (ii) the local narrow gorges across the Pokhara city, prone to dangerous blockages during flooding. Contrary to this, the Pokhara Formation, made of loose, gravels deposits (including a few gneissic boulders - like the Bhim Kali one - incorporated to the debris flow material during the mega floods), is

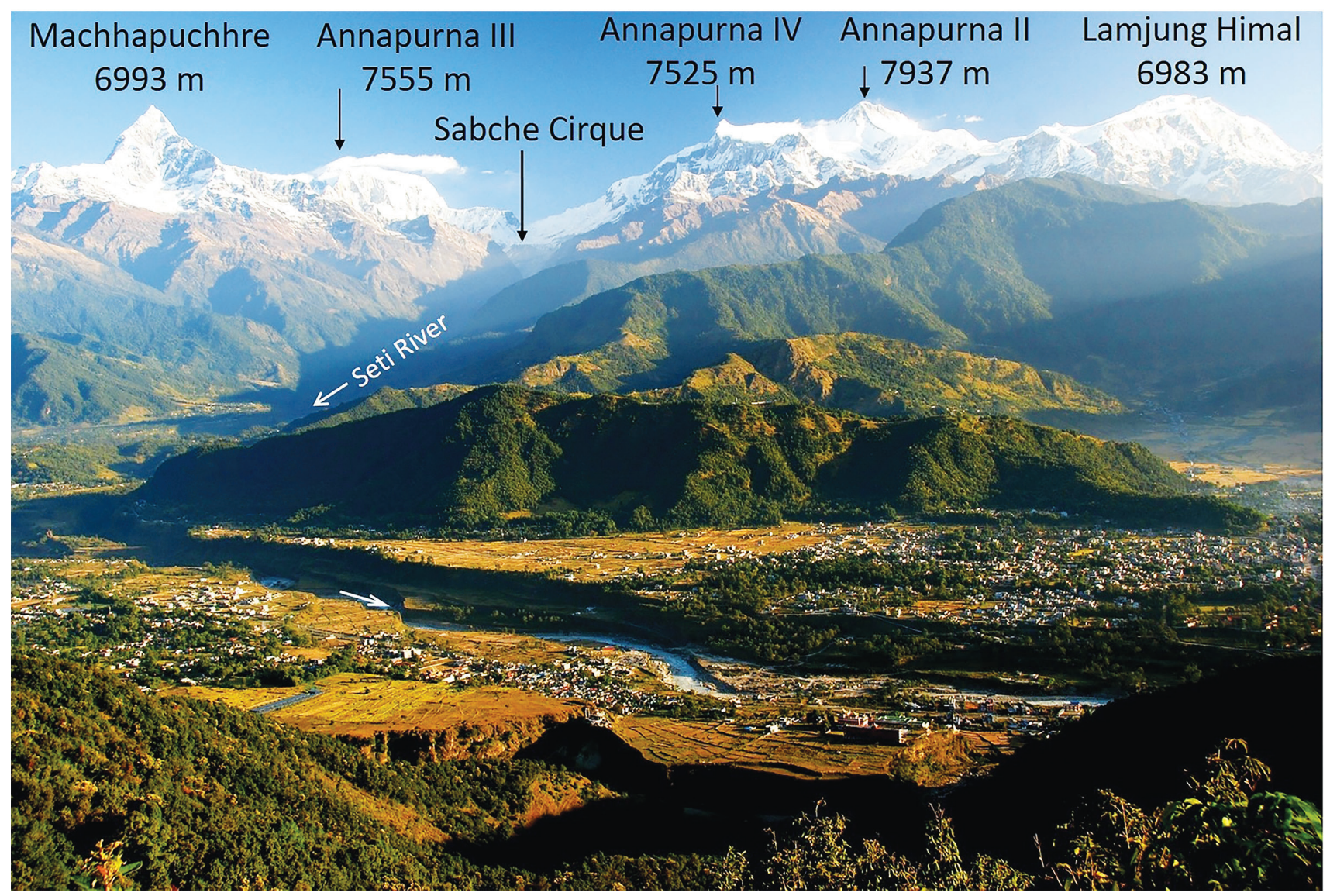

Fig. 2: Panoramic view of Machhapuchhre and Annapurnas from Pokhara showing the Sabche Cirque and the headwater of Seti catchment (Photo by M. Fort, 2013). 
much more erodible when Seti flood events do occur, so that widening of, and deepening across this Pokhara Formation are still efficient, continuous processes since the last medieval event (about six centuries back; Schwanghart et al., 2016; Stolle et al., 2017, 2019). Historically, the Pokhara site presented advantages for societies wishing to settle beyond the level of the highest floods of the Seti River, due to the relief created by the terraces complex. But for the last four decades, the settlement gradually migrated towards the lower terraces and alluvial plain, confronting local populations with the risk of flooding. the sky remains clear, although the atmosphere is cold and rather foggy in the morning (Burbank et al., 2003; Gabet et al., 2004; Fort et al., 2018). Since the Seti valley represents the highest precipitation area in Nepal with the steepest orographic gradient $(\sim 10 \%)$ where about $4.2-\mathrm{km}$ fall of the elevation in 44-km distance, the river is highly vulnerable to flood hazard. Therefore, the high hydrological variability in the Seti catchment, marked by three levels in the year, i.e. ordinary, monsoon and flood, complicates the relationship that locals have with the river.

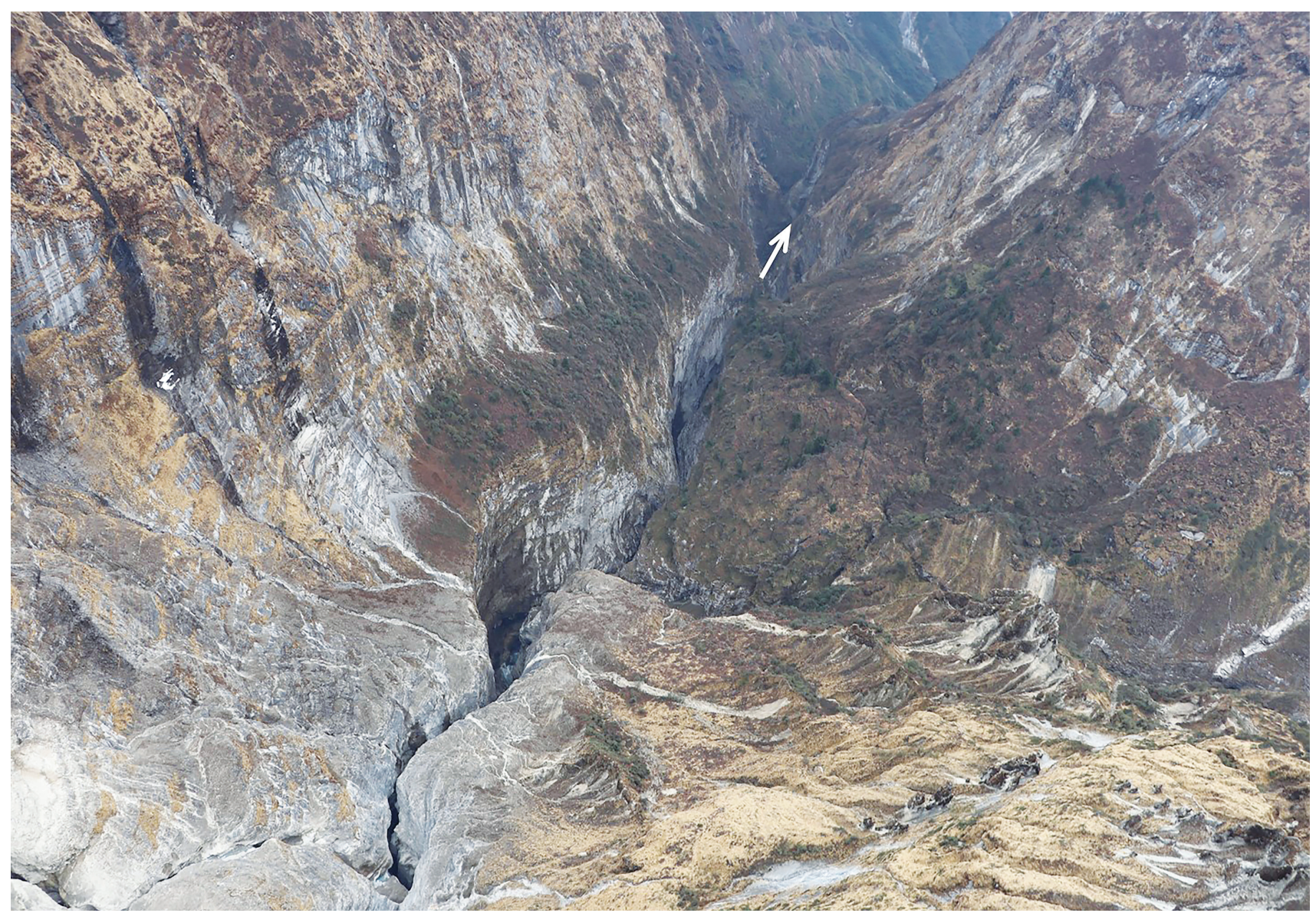

Fig. 3: Deep and narrow gorge of the Seti River at the outlet of Sabche Cirque. Avalanches and rock falls from the steep slopes of Machhapuchhre and Annapurnas frequently block this section (Photo by N. Gurung, 4 December 2020)

\section{CLIMATE AND HYDROLOGY}

The climate of the Seti valley is subtropical, with mountainous influences. The temperature varies between $30^{\circ} \mathrm{C}$ and $35^{\circ} \mathrm{C}$ in summer and $-2^{\circ} \mathrm{C}$ and $15^{\circ} \mathrm{C}$ in winter (Fort et al., 2018). The rainfall pattern is dominated by the monsoon circulation, with $80 \%$ of the total rainfall occurring from June to September. The average annual precipitation in Pokhara is $3951 \mathrm{~mm}$, with amounts exceeding $4800 \mathrm{~mm}$ in the Seti catchment (elevations $\approx 3000 \mathrm{~m}$ ) due to the orographic amplification, which makes Pokhara and the Seti valley the area receiving the highest annual precipitation in the country (DHM; Fort et al., 2018). In winter, the circulation of westerlies prevails and

\section{RELATIONSHIPS BETWEEN THE RIVER, ITS FLOODS AND THE INHABITANTS}

Many floods took place in the catchment but we consider the 2012 Seti flood because it impacted humans, infrastructures and river morphology noticeably (Fig. 4 and 5). It took lives of 72 people and damaged infrastructures worth millions of dollars (Dwivedi and Neupane, 2013, Kargel et al, 2014). The main damages took place in Saadal, Bharabhuri (Karuwa), Khaarpaani Tatopani, Seti Mureghat, Mardi Dovan, Hemja Bensi, Masina Bagar, Upallo Gosti and Tallo Gosti (dots 3 to 9, Fig. 1). The flood had also brought changes on river cross sections. The summary of impacts is given in Table 1. Many anthropogenic 
Hydro-torrential hazard vs. anthropogenic activities along the Seti valley, Kaski, Nepal
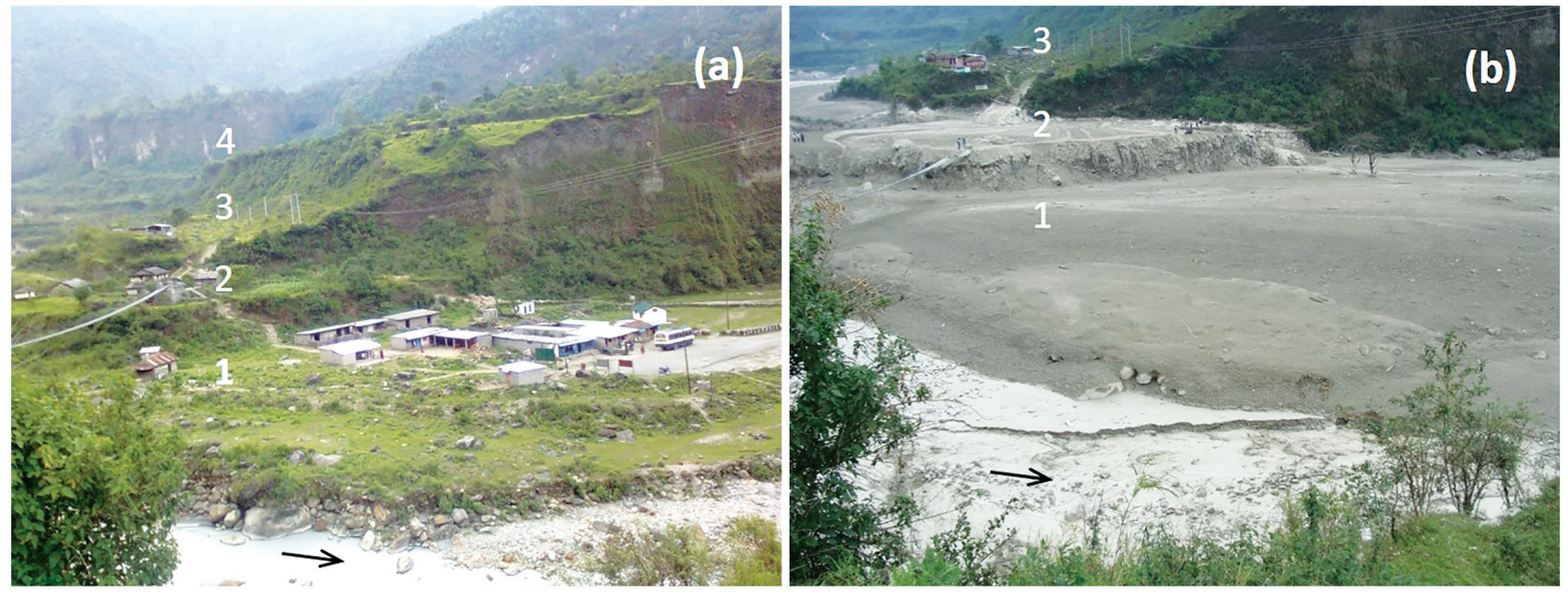

Fig. 4: View of Khaarpaani Tatopani [site 5, Fig. 1]. (a) Before (Photo by N. Gurung, 13 April 2012), and (b) After the May 5, 2012 Seti River flash flood (Photo by N. Gurung, 7 May 2012). This is where a total of 69 people died. 1: Lower terrace; 2: Middle terrace; 3: Higher terrace; 4: Top terrace. Both terraces 1 and 2 were completely flooded during the 2012 Seti flood. All terraces are made of Pokhara Formation loose gravels.
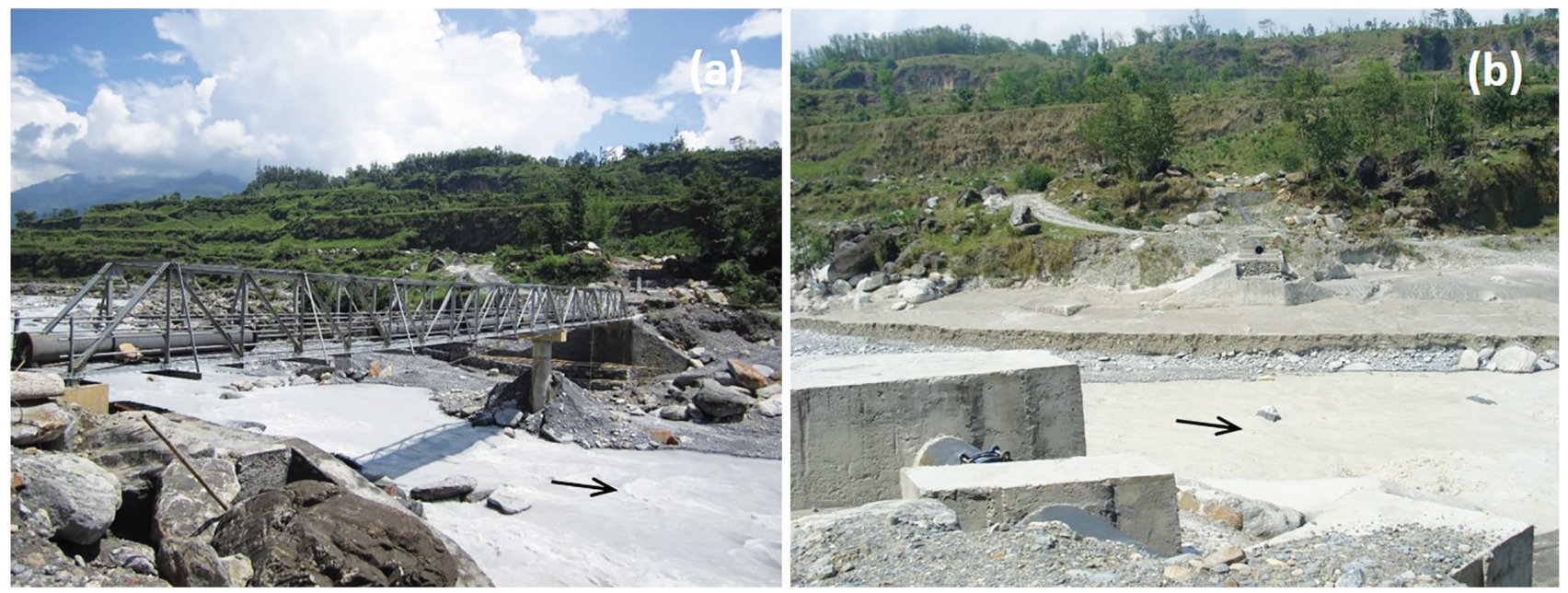

Fig. 5: The 42 m long steel truss bridge carrying drinking water pipes for Pokhara city at Hemja Bensi [site 8, Fig. 1]. (a) Before May 5, 2012 Seti flood (Photo by Nepal Water Supply Corporation, Pokhara Branch, 16 June 2011), and (b) After the flood. The bridge was completely swept away (Photo by N. Gurung, 14 May 2012).

activities (infrastructures and settlement) have taken place or are being built along the Seti valley since the 2012 flood (Table 2). If it is good to have development works for the benefits of both locals and the nation, the key concern is whether they have been built sustainably considering the hydro-geomorphological hazards, or whether their presence, are aggravating the fluvial risk further.

\section{METHODS}

This study was largely based on several field visits to the Seti River and its catchment area in the immediate aftermath of the Seti flood event in May 2012 and from January to December 2020. Airborne reconnaissance studies were carried out on 17 December 2020 in Sabche Cirque area. To conduct floodplain analysis and identify potential flood hazard areas along the Seti valley, a wide range of methods were applied that included measurement of river cross sections at many places along Seti River, measurement of the thickness of the alluvial material that was either deposited or eroded between each dates, analysis for the systemic approach of fluvial risk development, hydro-geomorphological mapping, one dimensional hydraulic modelling in HEC-RAS, analysis of the land use and land cover maps of the Seti catchment in ARC GIS using topographic survey map (1996), and Landsat 8 Satellite images for the year 2013 and 2020, and verifying them with Google Earth images and interviews with local people.

\section{SYSTEMIC ANALYSIS OF FLUVIAL RISK}

Flash floods are linked to predisposing factors (such as geological structure, slope, sediment yield, drainage density, shape of the hydrographic basin), triggering factors (such as rainfall in the catchment, earthquake, 
rock-fall, avalanche, GLOF) and aggravating factors (human activities, land use on the slopes and in the floodplains, intensity and duration of rainfall, snow cover, bottleneck channels; Bardou et al., 2003, Arnaud-Fassetta et al., 2009). As such the 2012 Seti flash flood was analysed on these aspects to see how the fluvial risk was developed in 2012 and further how it is being developed along the Seti valley from
2012 onwards. A detail of the systemic approach of the fluvial risk developed along the Seti valley, which ultimately led to the 2012 disastrous flood is presented (Fig. 6). Though rainfall was not the only triggering factor for the 2012 Seti flood event, it often appears as the main trigger for more common floods in the Seti valley.

Table 1: Impacts of the 2012 Seti flood (Note: Location No. are given in Fig. 1).

\begin{tabular}{|c|c|}
\hline Location No. & Impact \\
\hline $\begin{array}{l}\text { 1. Seti River outlet from Sab- } \\
\text { che Cirque }\end{array}$ & $\begin{array}{l}\text { - Surrounding trees and shrubs were washed away. } \\
\text { - } \quad \text { River banks were heavily eroded. } \\
\text { - } \quad \text { A small landslide had taken place. }\end{array}$ \\
\hline 2. Jimirbaari & $\begin{array}{l}\text { - } 2 \text { houses were partly submerged and the area where intake of the upper } \\
\text { Seti hydropower project }(25 \mathrm{MW}) \text { is being built, was also flooded. }\end{array}$ \\
\hline $\begin{array}{l}\text { 3. Saadal, Ebang and Kapu- } \\
\text { che }\end{array}$ & $\begin{array}{l}\text { - Some area of Saadal and Ebang were flooded. } \\
\text { Two houses and a suspended bridge were swept away at Saadal and a } \\
\text { house was buried at Ebang. } \\
\text { - One woman and twenty-five domestic animals (goats and buffaloes) } \\
\text { were killed at Ebang. } \\
\text { - Bank erosion had taken place at Kapuche. } \\
\text { - The Seti River was dammed at Kapuche. }\end{array}$ \\
\hline 4. Bharabhuri Bagar & - A suspended bridge was partly damaged. \\
\hline $\begin{array}{l}\text { 5. Khaarpaani Tatopani (natu- } \\
\text { ral hot-spring site) }\end{array}$ & $\begin{array}{l}\text { - } 69 \text { people were either buried or washed away to their deaths. } \\
\text { - } \text { A suspended bridge was badly damaged. } \\
\text { - } 16 \text { houses were swept away. } \\
\text { - } \text { Road was washed-away. }\end{array}$ \\
\hline 6. Setimureghat & $\begin{array}{l}\text { A 54-m long suspended bridge was washed away along with sweeping } \\
\text { away of one man to his death. }\end{array}$ \\
\hline $\begin{array}{l}\text { 7. Mardi Dovan (confluence } \\
\text { of Mardi River and Seti } \\
\text { River) }\end{array}$ & $\begin{array}{l}\text { - Abutments of the steel truss bridge that is carrying drinking water main } \\
\text { pipes for Pokhara city was damaged. } \\
\text { - Some sections of drinking water pipes (for Pokhara city) were also } \\
\text { washed away. }\end{array}$ \\
\hline 8. Hemja Bensi Bridge site & $\begin{array}{l}\text { A 42-m long steel truss bridge that was built to cross drinking water } \\
\text { pipes for Pokhara city, was completely washed away. }\end{array}$ \\
\hline $\begin{array}{l}\text { 9. Masina Bagar, Upallo Gos- } \\
\text { ti and Tallo Gosti }\end{array}$ & $\begin{array}{l}\text { - The area was partly flooded. } \\
\text { - Some } 600-\mathrm{m} \text { long drinking water pipes for Pokhara city were washed } \\
\text { away. } \\
\text { - A woman was killed by the flood at Tallo Gosti. }\end{array}$ \\
\hline $\begin{array}{l}\text { 10. Kaseri (Laltin) Bazzar } \\
\text { and Shanti Tole }\end{array}$ & $\begin{array}{l}\text { Part of Shanti Bazzar was flooded. } \\
\text { - } 2 \text { houses were badly damaged. } \\
\text { - } \quad \text { Gabions for riverbank protection were washed away. }\end{array}$ \\
\hline $\begin{array}{l}\text { 11. Sukhawati Gumba and KI } \\
\text { Singh Bridge }\end{array}$ & $\begin{array}{l}\text { - The area was dammed and flooded. } \\
\text { - Gabions for riverbank protection were damaged and swept away. }\end{array}$ \\
\hline 12. Narayanthan & - The area was dammed and flooded. \\
\hline 13. Ramghat & - This was dammed and flooded. \\
\hline 14. Ratopahiro & - River-bank erosion and edge fall had taken place. \\
\hline
\end{tabular}


Table 2: Infrastructures built since the 2012 Seti flood.

\begin{tabular}{|c|c|}
\hline Location & Infrastructure development \\
\hline Jimirbaari & $\begin{array}{l}\text { - Intake of the upper Seti hydropower project ( } 25 \mathrm{MW}) \text { is being built. } \\
\text { - Buildings for hydropower have been built. } \\
\text { - Motor road is built along the right bank of the Seti River up to } \\
\text { Jimirbaari. }\end{array}$ \\
\hline Saadal and Ebang & $\begin{array}{l}\text { A suspended bridge over Seti, close to the bottle-neck channel at } \\
\text { Kapuche has been built. } \\
\text { Motor road has been built across Saadal and Ebang along the right bank } \\
\text { of the Seti River. }\end{array}$ \\
\hline Bharabhuri Bagar & $\begin{array}{l}\text { Power house of the upper Seti hydropower project }(25 \mathrm{MW}) \text { and intake } \\
\text { of the middle Seti hydropower project (24 MW) are being built in the } \\
\text { floodplain. } \\
\text { - Motor road is constructed along its right bank. }\end{array}$ \\
\hline $\begin{array}{l}\text { Khaarpaani Tatopani } \\
\text { (natural hot-spring site) }\end{array}$ & $\begin{array}{l}\text { - A new 58-m long motorable bridge is built. } \\
\text { - Motor road is also built to go to Mirsa and Karuwa through the new } \\
\text { bridge along the right bank. } \\
\text { - Headrace (penstock pipe) of middle Seti hydropower project (24 MW) } \\
\text { is being built along the left bank of the Seti River. } \\
\text { - Existing road along the left bank is being widened. } \\
\text { - A new suspended bridge is re-built. } \\
\text { - Hot-spring wells are re-built and a R.C.C. retaining wall is built for the } \\
\text { protection from flood. }\end{array}$ \\
\hline $\begin{array}{l}\text { Mardi Dovan (confluence of } \\
\text { Mardi River and Seti River) }\end{array}$ & $\begin{array}{l}\text { A } 60-m \text { long motorable bridge is built downstream of the confluence } \\
\text { (Mardi Dovan). } \\
\text { Motor road is built on the left bank of the Seti River to go to } \\
\text { Puranchaur. } \\
\text { - A crusher industry is set up on the left bank of the Seti River near the } \\
\text { confluence. } \\
\text { R.C.C. pillars and R.C.C. retaining wall have been built to support and } \\
\text { protect drinking water pipes. }\end{array}$ \\
\hline Hemja Bensi Bridge site & - A new $85.50-\mathrm{m}$ long suspended bridge is built. \\
\hline $\begin{array}{l}\text { Masina Bagar, Upallo Gosti } \\
\text { and Tallo Gosti }\end{array}$ & $\begin{array}{l}\text { - A motorable bridge is built at Masina Bagar. } \\
\text { - New houses have been built in Masina Bagar, Upallo and Tallo Gosti. } \\
\text { Pipeline of drinking water for Pokhara along the right bank across } \\
\text { Upallo Gosti, which was swept away by the } 2012 \text { flood, is re-built. } \\
\text { - A football ground is built on the left bank in the floodplain (to the west } \\
\text { of Upallo Gosti). }\end{array}$ \\
\hline $\begin{array}{l}\text { Kaseri (Laltin) Bazzar and } \\
\text { Shanti Tole }\end{array}$ & $\begin{array}{l}\text { - New houses have been built in Shanti Tole. } \\
\text { - } \quad \text { Now } 180 \text { households are residing in the floodplain in Shanti Tole alone. }\end{array}$ \\
\hline $\begin{array}{l}\text { Sukhawati Gumba and KI } \\
\text { Singh Bridge }\end{array}$ & $\begin{array}{l}\text { - New monastery building has been built in the floodplain. } \\
\text { - River trainings work (gabion wall) is built along the right bank of the } \\
\text { Seti River. }\end{array}$ \\
\hline Narayanthan & - A new motorable bridge is built. \\
\hline Ramghat & $\begin{array}{l}\text { - New houses have been built in the floodplain on the lower terrace of } \\
\text { Ramghat. } \\
\text { - New monastery building is built. } \\
\text { - An electric crematorium is being built. }\end{array}$ \\
\hline
\end{tabular}




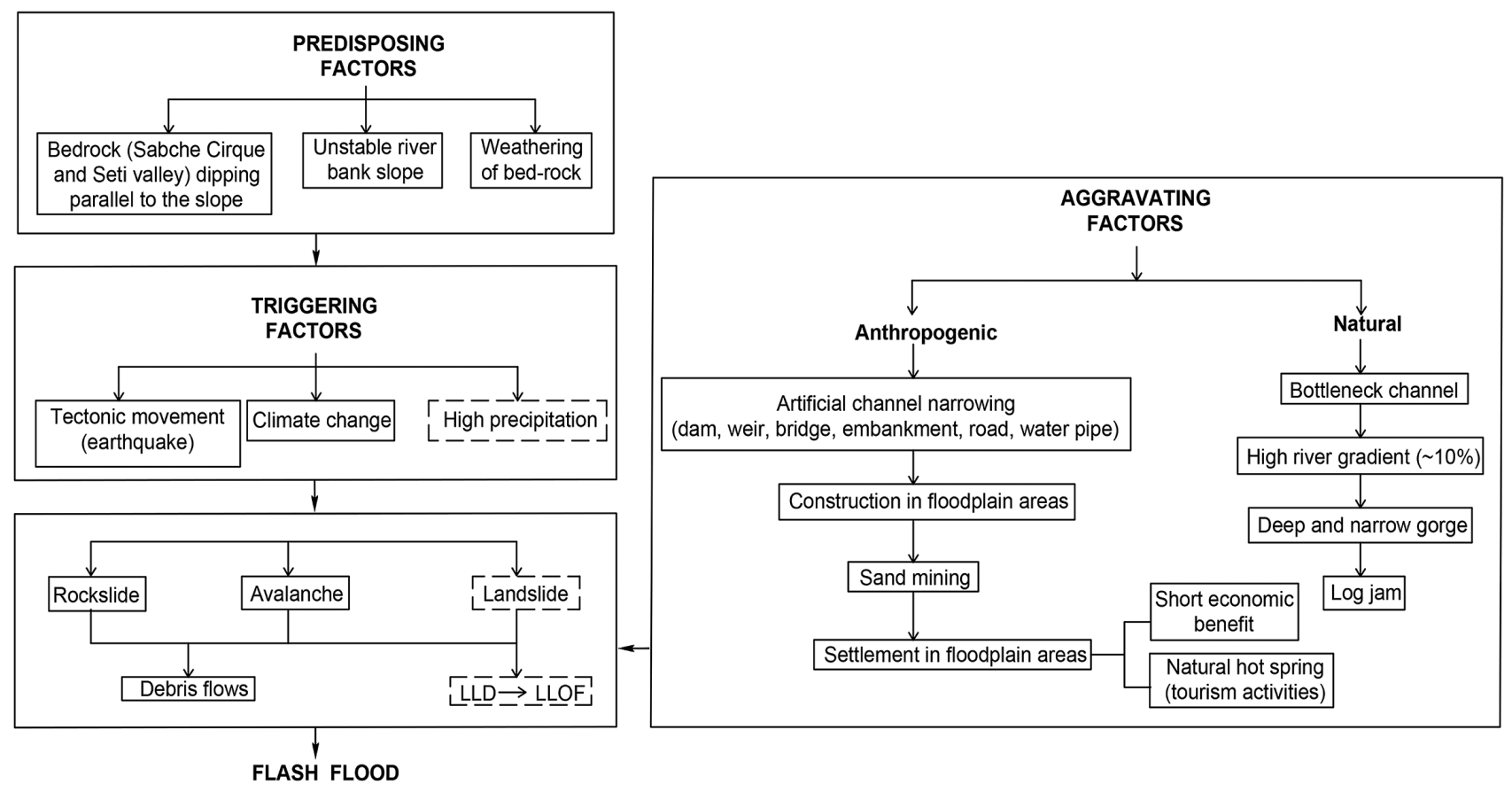

Fig. 6: Chart of the systemic approach to show how the flood risk is developed in the Seti catchment. Those shown within the dotted bracket were not applicable to the May 5, 2012 Seti flood event (Source: Adapted and modified from Malavoi et al., 1998 and Arnaud-Fassetta et al., 2009).

\section{HYDRO-GEOMORPHOLOGICAL MAPPING WITH DELINEATION OF RIVER FUNCTIONAL SPACE (OR FREEDOM SPACE OF RIVER)}

Hydro-geomorphological mapping allows to understand what are the potential geo-hazard areas and the maximum space naturally required for the free flow of river. We used the concept of "stream-way" or "freedom space" (Malavoi et al., 1998; ArnaudFassetta and Fort, 2009) which serves defining the "functional flooding area" in six steps: (i) Maximum flooding area (i.e., limits of the floodplain); (ii) Amplitude of active channel (i.e., active-channel length of the last "large" event in the valley); (iii) Historical wandering pattern (i.e., mapping of the palaeochannels); (iv) Residual wandering areas that may affect hydrological conditions (e.g., pile-bridge protection, embankments); (v) Potential erodible zones (i.e., over the next few years according to the river dynamics and the nature of the bank material); (vi) River space of good functionment, which is the synthesis from (i) to (v). From this mapping, one can have a clear information about where to live, or build infrastructures, or develop sustainable land use along the riverbanks. Hydro-geomorphological maps were prepared based on frequently flooded or actively eroding areas, riparian wetlands, engineering geological map, a comprehensive geomorphological hazard study and a gathering of information on previous events (including the 2012 flood event) based on aerial photos and video material, eyewitness reports from the local community and silent witnesses detected on-site (geomorphic features, traces of flood impacts, etc., as described in Kondolf and Piégay, 2003; Arnaud-Fassetta et al., 2009). According to these authors, the development of hydro-geomorphological mapping with the outlining of the river functional space (or freedom space for river) provides information about the fluvial risk and the space that a river requires for its natural flow without any hindrance. This gives information about which area is safe for the infrastructure construction and living (settlement), thus help for the sustainable fluvial risk mitigation. The fluvial risk can be assessed by identifying unstable reaches characterised by active channel shifting and those susceptible to be affected by important changes in channel geometry, thus delineating the potential zones of flood expansion and dissipation (Arnaud-Fassetta et al., 2009). To that end, the hydro-geomorphological mapping with delineation of the river functional space have been prepared for four representative sites (Khaarpaani Tatopani, Mardi Dovan, Masina Bagar- Upallo Gosti, and Kaseri Bazzar-Shanti Tole, red dots 5,7, 9 and 10 in Fig. 1, respectively) to spatialise the active-channel dynamics, flooding zones, maximum flooding space connectivity between the river, and the slope. Field visits were conducted in January, March, April, November and December 2020, in addition to earlier visits in May 2012 and November 2014. More specifically, past events were reconstructed from geomorphological mapping, deduced from field observations, analysis of natural cross sections, and data provided by local people in order to have 
knowledge about past processes and events in the Seti catchment. Prepared hydro-geomorphological maps were subsequently checked in the field and updated as necessary.

\section{HYDROLOGICAL ANALYSIS}

Hydrologic analysis was conducted for designing peak flood for 2, 50 and 100-year's return periods. The analysis was based on the annual rainfall recorded at Pokhara airport (index no. 804) and Lumle rainfall gauge stations (index no. 814). Different methods (PCJ, Rational method, WECS/DHM method, Modified Dicken's formula and other) were used to calculate peak flood discharges for 2, 50 and 100 -year's return periods.

\section{Prem Chandra Jha (PCJ) Method}

PCJ method (Jha, 1996) was used to estimate the peak flood (Table 3) and this was compared with results obtained by other methods (e.g. Sharma and Adhikari, 2004; Table 4). Average peak flood values from Lumle and Pokhara airport stations were found to be $2118 \mathrm{~m}^{3} / \mathrm{s}$ and $2423 \mathrm{~m}^{3} / \mathrm{s}$ by PCJ method for the return period of 50 years and 100 years, respectively (Table 3). The PCJ method (Jha, 1996) calculates the design peak flood discharge based on hourly rainfall intensity. This method employs the formula, $Q_{p}=$ $16.67 \mathrm{a}_{\mathrm{p}} \mathrm{O}_{\mathrm{p}} \Phi \mathrm{F} \mathrm{k} \mathrm{f}_{\mathrm{f}}+\mathrm{Q}_{\mathrm{s}}$, where $\mathrm{Q}_{\mathrm{p}}=$ maximum rainfall design discharge for required exceedance probability in $\mathrm{m}^{3} / \mathrm{s}, \mathrm{a}_{\mathrm{p}}=$ maximum rainfall design intensity for required exceedance probability in $\mathrm{mm} / \mathrm{min}=\mathrm{a}_{\mathrm{hr}}$. $\mathrm{k}_{\mathrm{t}}$, where $\mathrm{a}_{\mathrm{hr}}=$ hourly rainfall intensity for required exceedance probability at selected rainfall stations in $\mathrm{mm} / \mathrm{min}, \mathrm{k}_{\mathrm{t}}=$ reduction coefficient of hourly rainfall intensity that depends on the catchment size, $\mathrm{O}_{\mathrm{p}}=$ infiltration coefficient of the basin, derived as the function of exceedance probability, $\Phi=$ areal reduction coefficient of maximum rainfall discharge that depends on the catchment size, $\mathrm{F}=$ catchment area of drainage basin in $\mathrm{km}^{2}, \mathrm{k}_{\mathrm{f}}=$ coefficient for unequal distribution of rainfall in different size of basin, captured by one rain, and $\mathrm{Q}_{\mathrm{s}}=$ discharge by melting of snow, which can be taken as 0 to $10 \%$ of $\mathrm{Q}_{\mathrm{p}}$ in the absence of data.

\section{Rational Method}

In this method, the discharge was computed by using empirical formula, i.e., $\mathrm{Q}=[(\mathrm{CIA}) / 1000]$, where $\mathrm{Q}$ $=$ the design flow $\left(\right.$ in $\left.\mathrm{m}^{3} / \mathrm{s}\right), \mathrm{I}=$ the rainfall intensity (in $\mathrm{mm} / \mathrm{h}$ ), $\mathrm{A}=$ the catchment area (in hectares), and $\mathrm{C}=$ the run-off coefficient (Mulvaney, 1851; Kuichling, 1889; Shrestha, 2008; Rijal, 2014). In the Seti catchment, $A=586.36 \mathrm{~km}^{2}=586360$ hectares (area above $5000 \mathrm{~m}$ elevation is $72 \mathrm{~km}^{2}$ and area below $3000 \mathrm{~m}$ elevation is $514.36 \mathrm{~km}^{2}$ ), $\mathrm{c}=0.3$ (as the catchment is vegetated), and Q was computed for the peak rainfall intensity. The catchment area was calculated from 30-m resolution Digital Elevation Model (DEM) prepared in ArcGIS from Landsat 8 satellite image and later verified with computation from Google earth map.

\section{Water and Energy Commission Secretariat (WECS) Method}

This method was developed for estimating the peak flow of the ungauged catchments of Nepal. (WECS/ DHM, 1990). The WECS/DHM was later updated by Sharma and Adhikari (2004) based on long-term data. They proposed the following equations for instantaneous peak-flow estimation. For 2-year's return period, $\mathrm{Q}_{2}=2.29\left(\mathrm{~A}_{3000}\right)^{0.86}$, for 100-year's return period, $\mathrm{Q}_{100}=20.7\left(\mathrm{~A}_{3000}\right)^{0.72}$, and for 50-year's return period, $\mathrm{Q}_{50}=\exp ^{2\left[\ln _{2}+2.054\left[\left\{\left(\ln \left(\mathrm{Q}_{100} / \mathrm{Q}_{2}\right)\right\} /(2.326)\right]\right.\right.}$, where $\mathrm{Q}$ is the discharge (in $\mathrm{m}^{3} / \mathrm{s}$ ), and $\mathrm{A}_{3000}$ is the catchment area (in $\mathrm{km}^{2}$ ), under 3000-m elevation. A 100-year's return period is often taken to design major bridges in Nepal, hence only $\mathrm{Q}_{100}$ was computed by this method.

\section{Modified Dicken's Formula Method}

This is a widely used method in Nepal (Rijal, 2014), which calculates the peak flood discharge, $Q_{\mathrm{f}}=\mathrm{C}_{\mathrm{T}}$ $\mathrm{A}^{3 /,}, C_{T}=2.342\left(\log (0.6 T)\left(\log \left(\frac{1185}{P}\right)\right)+4, P=\frac{A_{s}+6}{A+a}\right.$ where, $\mathrm{A}$ and $\mathrm{A}_{\mathrm{s}}$ $=$ the total catchment area and snow covered area, respectively in $\mathrm{km}^{2}$, and $\mathrm{T}=$ return period in years.

\section{HEC-RAS Modelling for Road Bridges}

HEC-RAS (2016) was used to analyse the high flood level across bridge sections. The peak discharges computed from different methods were compared (Table 4). Though a higher peak discharge value is computed by Rational method (Table 4), the peak value obtained from PCJ method was used for HECRAS analysis since PCJ method is considered to be a more reliable method (Rijal, 2014). The HECRAS modelling was performed for the peak flood of 100 -year's return period to determine the water surface profile along bridge cross-section of Khaarpaani Tatopani and Mardi Dovan since road bridges are normally designed for 100-year's return period in Nepal. River cross-sections were measured (with a margin of error of $\pm 10 \%$ ) to perform hydrological analysis in HEC-RAS (2016) and to compute hydraulic data required for the design of a road bridge. A total of fifteen cross-sections were measured in the field along $1.5 \mathrm{~km}$ length both downstream and upstream of each bridge section at $100 \mathrm{~m}$ intervals and a longitudinal section of the Seti River for both bridge sites. HECRAS is a system software, which is capable of performing one dimensional steady flow analysis (for 
gradually varied flow) among many other capabilities (HEC-RAS, 2016). River geometry, roughness coefficient, and flood discharge are three important parameters for the hydraulic modelling in HEC-RAS. In the hydraulic modelling of the Seti River, channel geometry parameters were measured directly from the field survey. Since the Seti River is a mountainous steep stream with boulders, Manning's roughness coefficient was assumed to be 0.05 based on the riverbed material and mixed flow regime (Arcement and Schneider, 1989). With the available data, a steady flow model was constructed with energy gradient as a boundary condition and the flow assumed to be as a mixed regime because the bed slope is variable and is expected to encounter both sub-critical and supercritical flow. The HEC-RAS models generated water surface elevations (free board) at different crosssections including the road bridge section, which was the main matter of concern for this study. The model was run with the flow regime to be as supercritical flow regime. The provided high flood water level of the bridge on the ground and computed high flood level by the HEC-RAS modelling were compared to check the suitability of the bridge for the peak flood.

Table 3: Peak-floods calculation using PCJ method.

\begin{tabular}{lrrr}
\hline \multirow{2}{*}{$\begin{array}{l}\text { Rainfall } \\
\text { station: }\end{array}$ Pokhara } \\
\cline { 2 - 4 } Airport (804) & \multicolumn{3}{c}{ Return period in years } \\
\cline { 2 - 4 } & \multicolumn{2}{c}{ Rainfall intensity in $\mathrm{mm} / \mathrm{h}$} \\
\cline { 2 - 4 } & \multicolumn{1}{c}{106} & \multicolumn{1}{c}{118} \\
\hline Parameters & & & \\
$\mathrm{K}_{\mathrm{t}}$ & 0.86 & 0.86 & 0.86 \\
$\mathrm{a}_{\mathrm{p}}$ & 1.22 & 1.85 & 1.99 \\
$\mathrm{O}_{\mathrm{p}}$ & 0.45 & 0.87 & 0.96 \\
$\Phi$ & 0.152 & 0.152 & 0.152 \\
$\mathrm{~K}_{\mathrm{f}}$ & 0.996 & 0.996 & 0.996 \\
$\mathrm{~F}$ & 614.36 & 614.36 & 614.36 \\
$\mathrm{Q}$ (in m$/ \mathrm{s}$ ) & 634 & 2117 & 2420 \\
\hline
\end{tabular}

\begin{tabular}{|c|c|c|c|}
\hline \multirow{4}{*}{$\begin{array}{l}\text { Rainfall } \\
\text { station: } \\
\text { Lumle } \\
(814)\end{array}$} & \multicolumn{3}{|c|}{ Return period in years } \\
\hline & 2 & 50 & 100 \\
\hline & \multicolumn{3}{|c|}{ Rainfall intensity in $\mathrm{mm} / \mathrm{h}$} \\
\hline & 110 & 130 & 143 \\
\hline
\end{tabular}

\section{Parameters}

$\begin{array}{lrrr}\mathrm{K}_{\mathrm{t}} & 0.86 & 0.86 & 0.86 \\ \mathrm{a}_{\mathrm{p}} & 1.24 & 1.78 & 1.96 \\ \mathrm{O}_{\mathrm{p}} & 0.42 & 0.84 & 0.98 \\ \Phi & 0.158 & 0.158 & 0.158 \\ \mathrm{~K}_{\mathrm{f}} & 0.994 & 0.994 & 0.994 \\ \mathrm{~F} & 614.36 & 614.36 & 614.36 \\ \mathrm{Q}\left(\text { in m }^{3} / \mathrm{s}\right) & 639 & 2119 & 2426\end{array}$

Average discharge based on 804 and 814

\begin{tabular}{llll}
$\mathrm{Q}\left(\right.$ in $\left.\mathrm{m}^{3} / \mathrm{s}\right)$ & 636.5 & 2118 & 2423 \\
\hline
\end{tabular}

Table 4: Comparison of peak-flood discharges computed from different methods.

\begin{tabular}{clc}
\hline Ser & \multicolumn{1}{c}{ Method } & $\begin{array}{c}\text { High-flood } \\
\text { discharge (in } \\
\mathrm{m}^{3} / \mathrm{s} \text { ) for } \\
\mathrm{T}=100 \text { years }\end{array}$ \\
\hline 1 & PCJ method & 2423 \\
2 & Rational method & 2726 \\
3 & Sharma and Adhikari & 1620 \\
& (2004) method & 1820 \\
\hline
\end{tabular}

\section{ANALYSIS OF LAND USE AND LAND COVER CHANGE (LULCC)}

LULCC analysis were done first for the whole Seti catchment including Pokhara valley and then for specific sites along Seti River. The first analysis was done to know the overall changes of LULC in the whole study area and second analysis were carried out know the LULC changes in particular sites.

\section{Seti catchment including Pokhara Valley}

Land-use and land-cover changes (LULCC) in the Seti catchment including Pokhara valley for an area of $1,165.10 \mathrm{~km} 2$ were prepared and analysed for the years 1996, 2013 and 2020. The LULC map for 1996 was prepared based on the topographic survey map of 1996 (scale 1:25,000), and for 2013 and 2020 from Landsat 8 satellite images of $30-\mathrm{m}$ resolution. Along with topographic survey map of 1996, the two cloud-free Landsat 8 satellite images were used to prepare LULC maps of the Seti catchment: Landsat Image 8 with Path/Row 142/40 of 15 April 2013 and Landsat 8 with Path/Row 142/40 of 17 March 2020 were downloaded from the USGS Earth explorer website. All data were projected to the Universal Transverse Mercator (UTM) projection system in ArcGIS 10.5 and ArcGIS 10.5 image classification module was used for the image analysis. After preprocessing, images of each year were classified by the supervised classification technique in ArcGIS 10.5 image classification. The use of correction techniques in ArcGIS 10.5 improved the qualities of the classified images and reduced the error rates in the post-processing stage. Since Land Use and Land Cover (LULC) map of 1996 was prepared from the topographic survey map of Nepal, its accuracy is more than $95 \%$, while accuracy of Landsat 8 images ( $30 \mathrm{~m}$ resolution) is said to be more than $85 \%$ from the publisher (https://earthexplorer.usgs.gov);since 2020 map was verified on the ground, accuracy of LULC maps of 2013 and 2020 is more than $85 \%$. Model builder in ArcGIS 10.5 was applied to analyse the changes, transition and exchanges of LULC. Eleven LULC classes were considered viz., urban / built-up, 
water body, open field, forest cover, cultivated land, sandy area, glacier, snow cover, barren land, grass land and swamp area. The produced LULC images were analysed and changes between the years quantified.

\section{Specific Sites}

The LULCC maps for four specific sites were prepared and analysed in Arc GIS 10.5 by using Google Earth maps of 2004, 2013 and 2021: Khaarpaani Tatopani (dot 5, Fig. 1), Mardi Dovan (dot 7, Fig. 1), Masina Bagar-Gosti (dot 9, Fig. 1) and Kaseri (Laltin Bazzar; dot 10, Fig. 1). Six LULC classes were considered viz., urban / built-up, water body, open field, forest cover, cultivated land, and floodplain. The produced LULC images were analysed and changes between the years quantified.

\section{INTERVIEWS WITH LOCAL PEOPLE}

Interviews and interactions with local inhabitants at Saadal, Ebang, Bharabhuri, Khaarpaani, Masina Bagar, Upallo Gosti, Kaseri Bazzar, Shanti Bazzar, Ramghat were carried out to gather information about the past flood events, development activities, damages made by the past events, awareness about the risks posed by possible floods, governments' action towards fluvial risk management, and about the time when they started to live in riverbanks.

\section{RESULTS}

\section{Hydro-torrential Hazards versus Anthropogenic Activities}

From the hydro-geomorphological mapping of the four representative sites [Fig. 7 (a), 8 (a), 9 and 10 (a)], it is clear that most anthropogenic activities and river-bank settlements along the Seti valley have taken place (or are being taken) within the river functional space. That means these infrastructures and settlements are vulnerable to high floods, such as at Khaarpaani Tatopani (Fig. 11), and at Masina Bagar and Upallo Gosti (Fig. 12). As shown by the hydro-geomorphological map of Khaarpaani Tatopani [Fig. 7 (a)], the motorable bridge, road and suspended bridge have been built within the river functional flooding space, hence these are susceptible to high floods. As such, these areas in Khaarpaani Tatopani were also flooded during the 2012 flood [Fig. 13 (a)]. The fluvial risk has been increased further by anthropogenic activities such as construction of houses and infrastructures in the floodplains along the Seti River encroaching flood ways and without considering the impact of 2012 Seti flood (Fig. 13 and 14).

\section{Bridges Susceptible to High Floods}

Many infrastructures built after the 2012 flood in the
Seti valley seem to be vulnerable to extreme floods. As such, from the HEC-RAS analysis both $58 \mathrm{~m}$ long motorable bridge built over the Seti River at Khaarpaani Tatopani and $60 \mathrm{~m}$ long motorable bridge built over the Seti River at Mardi Dovan (confluence of Seti River and Mardi River) seem vulnerable to peak floods [Fig. 7 (b), 8 (b)]. The provided freeboard of the Seti bridge (Khaarpaani Tatopani) is found to be insufficient for the extreme flood of 100-year's return period [Fig. 7 (b)]. The computed highest watersurface elevation for the 100-year's return period peak flood discharge at the bridge section is 1244.06 $\mathrm{m}$, which is $4.26 \mathrm{~m}$ (1244.06 m minus $1239.80 \mathrm{~m})$ above the bottom level of the deck or $0.96 \mathrm{~m}$ (1244.06 $\mathrm{m}$ minus $1243.10 \mathrm{~m}$ ) above the top level of the deck. Similarly, from the HEC-RAS model analysis, the freeboard of the Seti bridge at Mardi Dovan is found to be insufficient for the extreme flood of 100-year's return period [Fig. 8 (b)]. The computed highest water-surface elevation for 100-year's extreme flood discharge at the bridge section is $1033.90 \mathrm{~m}$, which is $0.95 \mathrm{~m}(1033.90 \mathrm{~m}$ minus $1032.95 \mathrm{~m})$ above the bottom level of the deck. That means the river flow is constricted at the bridge location due to the insufficient flow area to safely pass the extreme flood discharge. The river flow width is also reduced due to the construction of dykes, walls, roads on the right bank of the Seti bridge (Khaarpaani Tatopani) [Fig. 7 (b)]. and on both banks of Mardi Dovan bridge [Fig. 8 (b)]. This will cause the damage to the bridge due to (i) the constriction in flow area required for the safe discharge of extreme flood, and (ii) the large amount of debris (both mineral and vegetal) that may have come along with the flow at the time of flood event. Further, the narrow cross sections developed after the construction of bridges at these locations restrict the flow area causing abrupt rise in the water level during flooding, thus making them even more vulnerable to high floods.

\section{Impacts Analysis of the 2012 Seti Flood}

Many infrastructures were damaged or washed away by the 2012 Seti flood along with the death of 72 people and many domestic animals (Table 1). The main reasons for the destruction of infrastructures were found to be insufficient freeboard, i.e., the height of structures was less than the 2012 Seti flood water level, and the construction of infrastructures (houses, bridges, drinking water pipes) in floodplain areas within the river functional flooding space. Further, the 2012 Seti flood had brought changes on the river morphology. River cross-sections at five places were measured to assess the impact before and after the 2012 Seti flood (Fig. 15) and it was observed that there was more deposition than erosion in 2012 Seti flood $\left(34,070 \pm 3,407 \mathrm{~m}^{3}\right.$ vs. 9,920 $\pm 992 \mathrm{~m}^{3}$; Table 5). 


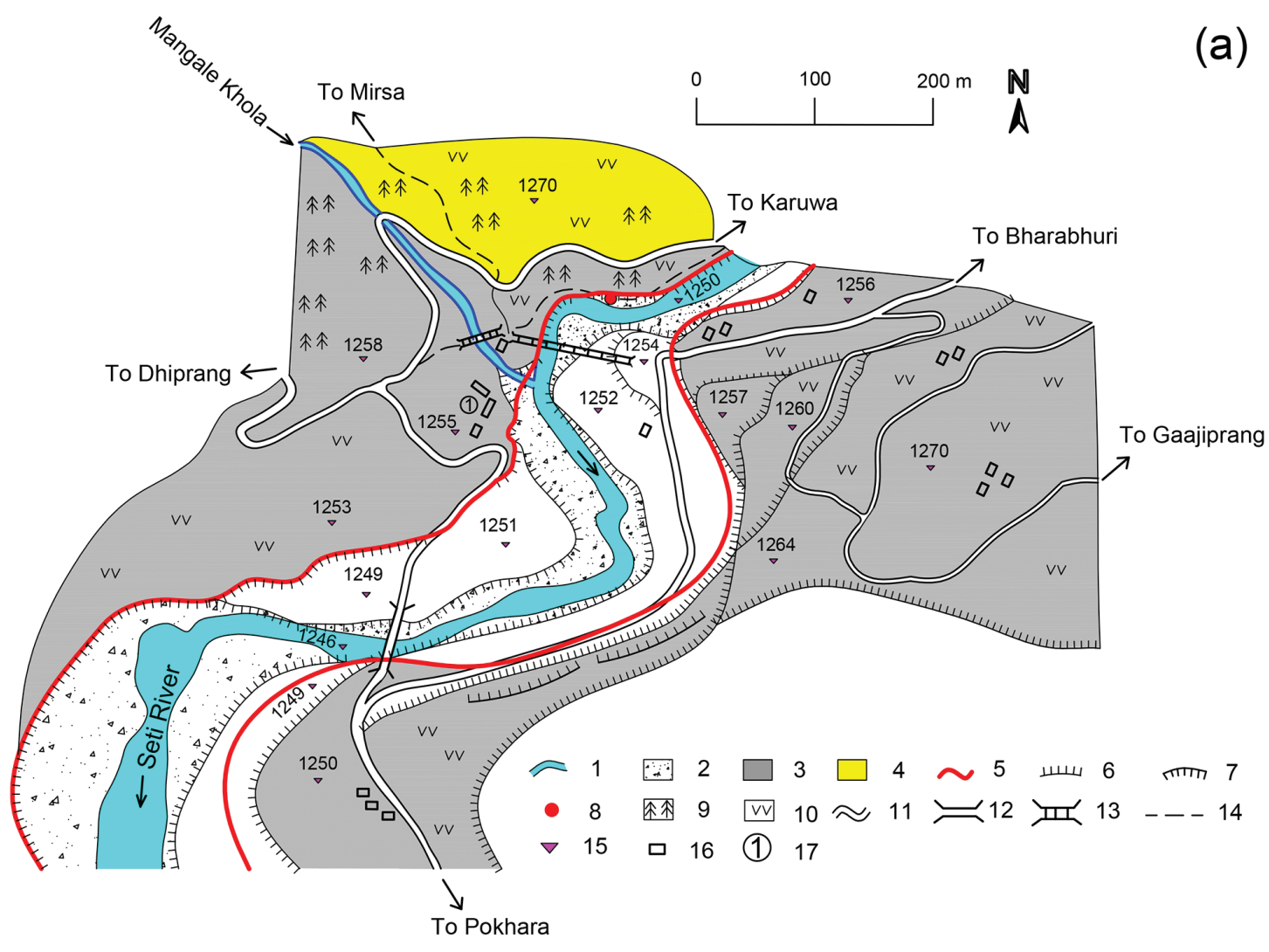

(b)

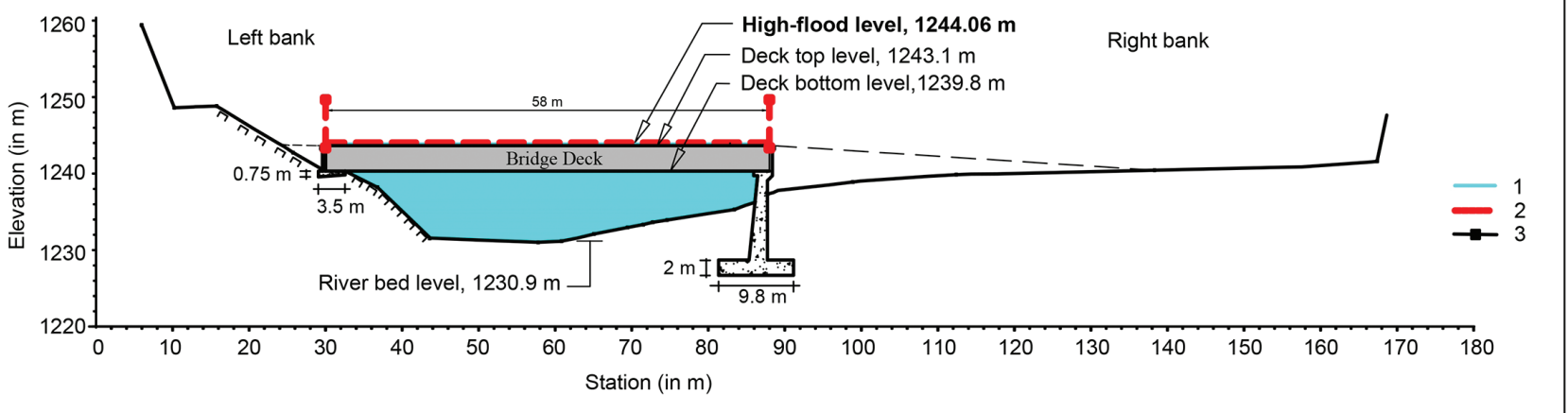

Fig. 7: Khaarpaani Tatopani [site 5, Fig. 1]. (a) Hydro-geomorphological map of Khaarpaani Tatopani with outlining the river functional space. 1: Ordinary (present) water flow channel; 2: River bed (monsoon and flood levels); 3: Lower terraces: loose gravels deposited by Pokhara formation; 4: Higher terrace: Ghachok Formation; 5: Boundary for the river functional flooding space; 6: Terrace edge; 7: Edge fall and river bank collapse; 8: Natural hot-spring; 9: Tree; 10: Bush; 11: Motor road; 12: Motorable bridge; 13: Suspended bridge; 14: Foot path; 15: Ground elevation in m; 16: Building; 17: School. (b) Newly built 58 m long Khaarpaani Tatopani bridge modelling in HEC - RAS software (version 5.0.3) in order to check its suitability for the Seti River peak flood discharge of 100 years. The computed highest water-surface elevation from HEC - RAS analysis is $1244.06 \mathrm{~m}$, which is $4.26 \mathrm{~m}$ $(1244.06 \mathrm{~m}$ minus $1239.80 \mathrm{~m})$ above the bottom level of the deck or, $0.96 \mathrm{~m}$ (1244.06 $\mathrm{m}$ minus $1243.10 \mathrm{~m})$ above the top level of the deck. This shows that the bridge is at high risk to extreme flood of 100 years. 1: Water surface profile; 2: Level of high flood level; 3: Ground level. 

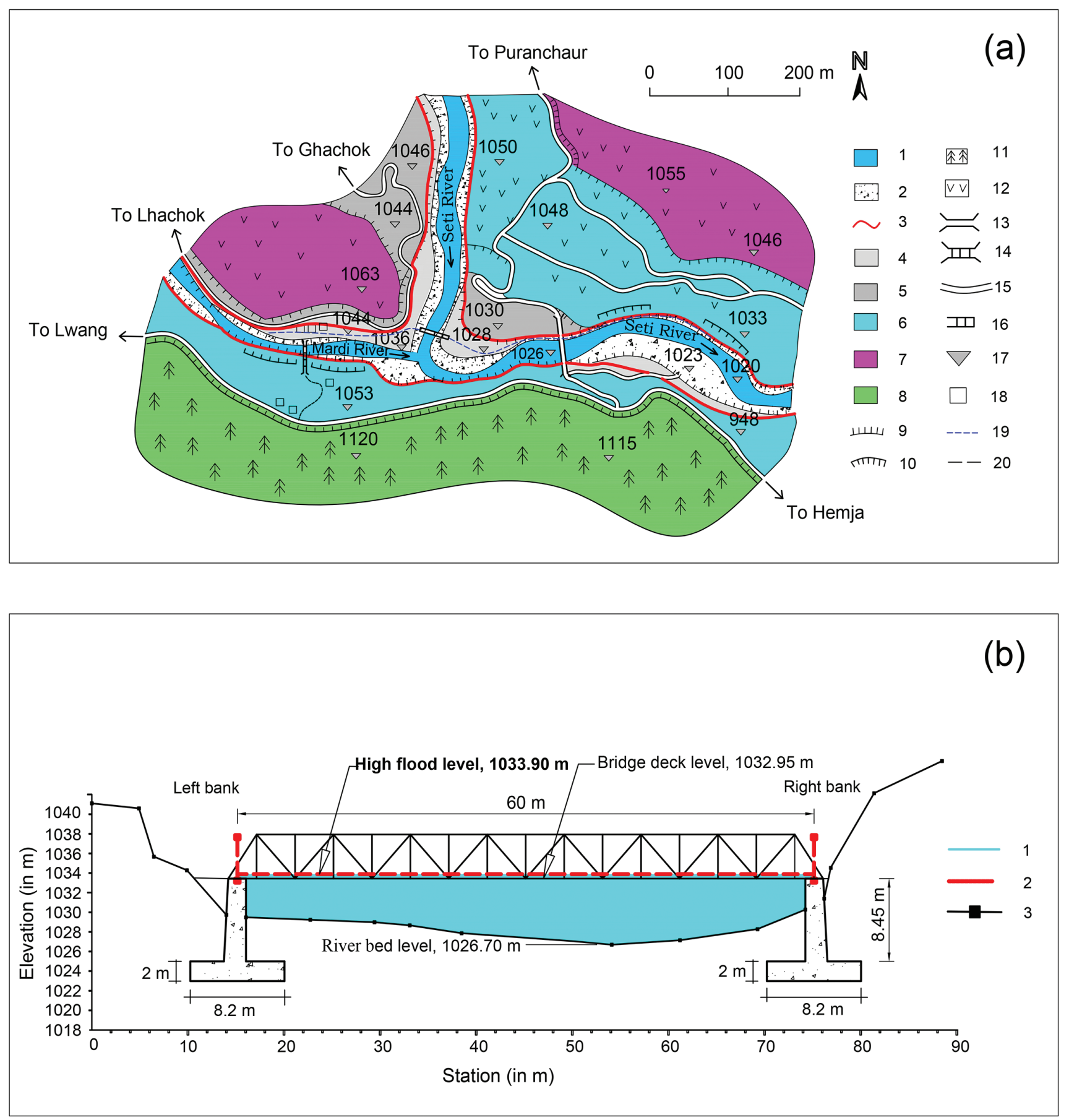

Fig. 8: Mardi Dovan (confluence of Seti River and Mardi River) [site 7, Fig. 1]. (a) Hydro-geomorphological map of Mardi Dovan with outlining the river functional space. 1: Ordinary (present) water flow channel; 2: River bed (monsoon and flood levels); 3: Boundary for the river functional flooding space; 4: Lower terrace; 5: Medium terrace; 6: Higher terrace (Pokhara Formation) - Seti River alluvium deposit overlain by landslide deposit; 7: Top terrace (Ghachok Formation) - Seti River alluvium deposit; 8. Hill slope (Kuncha Formation); 9 : Terrace edge; 10: Edge fall and river-bank collapse; 11: Tree; 12: Shrubs; 13: Motorable bridge; 14: Suspended bridge; 15: Motor road; 16: Bridge for water pipe crossing; 17: Ground elevation in m; 18: Building; 19: Drinking water pipe line for Pokhara; 20: Foot path. (b) $60 \mathrm{~m}$ long Mardi Dovan bridge modelling in HEC- RAS software (version 5.0.3) in order to check its suitability for the peak flood discharge of 100 years. The computed highest water-surface elevation for 100 year's extreme flood discharge at the bridge location is $1033.90 \mathrm{~m}$, which is $0.95 \mathrm{~m}(1033.90 \mathrm{~m}$ minus $1032.95 \mathrm{~m})$ above the bottom level of the deck. This shows that the bridge is at high risk to extreme flood of 100 years. 1: Water surface profile; 2: Level of high flood level; 3: Ground level. 


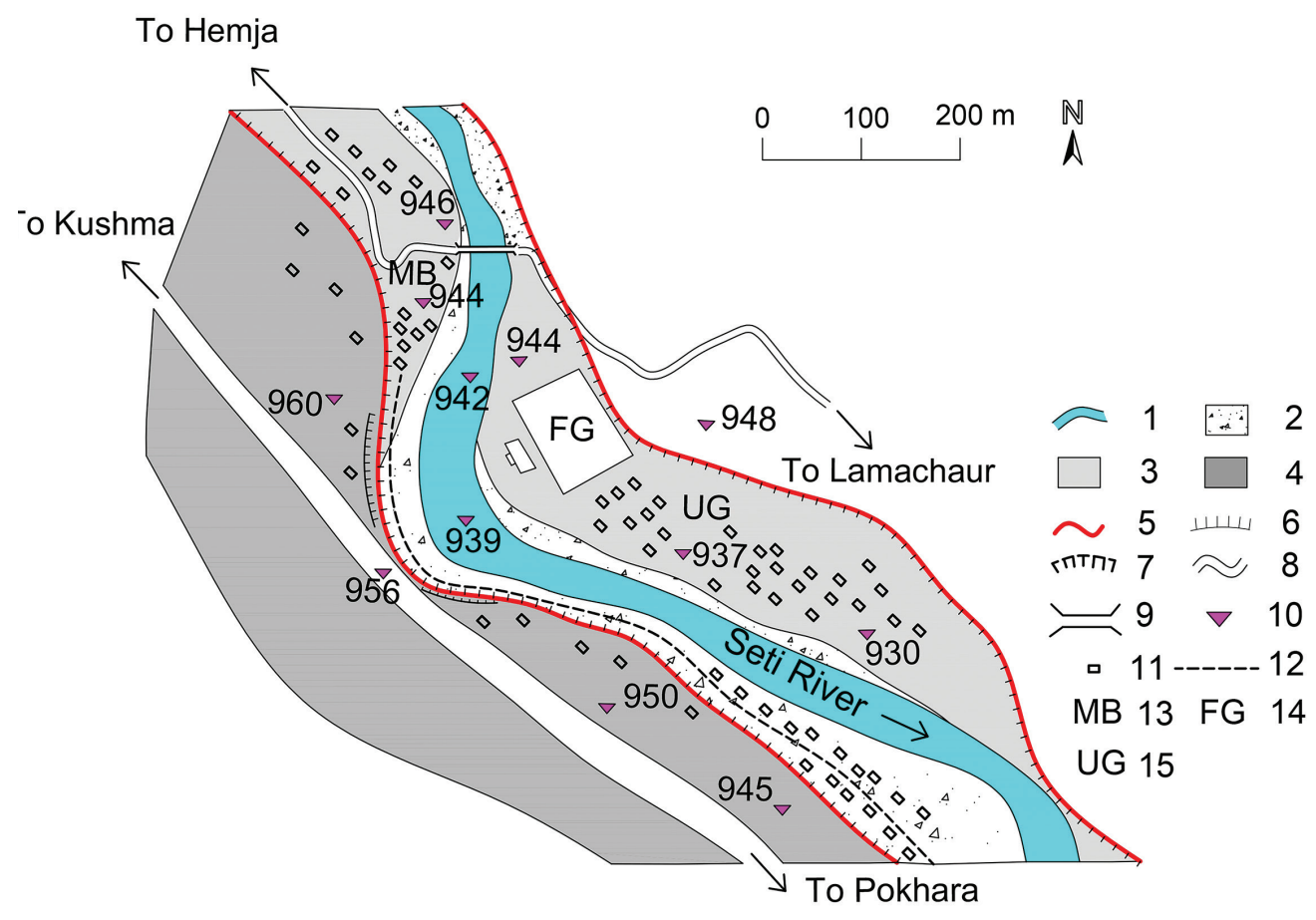

Fig. 9: Hydro-geomorphological map of Masina Bagar and Upallo Gosti with outlining the river functional space [site 9, Fig. 1]. 1: Ordinary (present) water flow channel; 2: River bed (monsoon and flood levels); 3: Floodplain; 4: Higher terrace: loose gravels deposited by Pokhara formation; 5: Boundary for the river functional flooding space; 6: Terrace edge; 7: Edge fall and River bank collapse; 8: Motor road; 9: Motorable bridge; 10: Ground elevation in m; 11: Building; 12: Drinking water pipe line for Pokhara city; 13: Masina Bagar (MB); 14: Football ground (FG); 15: Upallo Gosti (UG).
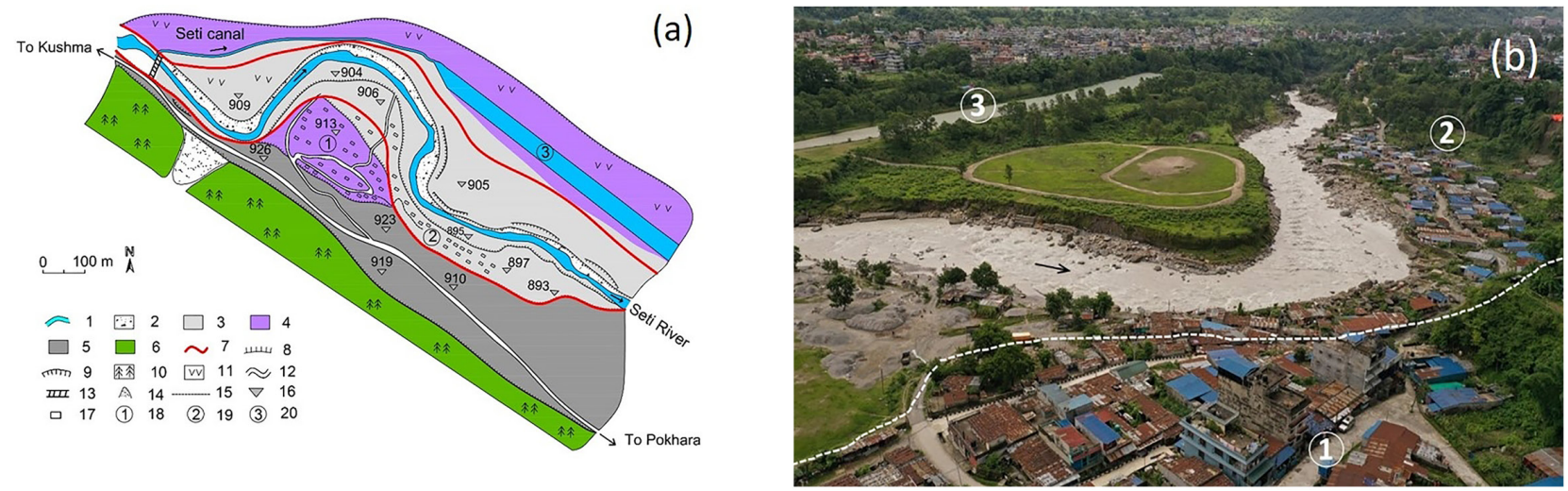

Fig. 10: Kaseri Bazzar (a.k.a. Laltin Bazzar) and Shanti Tole with outlining of the river functional space [site 10, Fig. 1]. (a) Hydro-geomorphological map of Kaseri Bazzar (Laltin Bazzar) and Shanti Tole with outlining of the river functional space. 1: Ordinary (present) water flow channel; 2: River bed (monsoon and flood levels); 3: Floodplain; 4: Middle terrace; 5: Top terrace (Pokhara formation loose gravel deposition); 6: Hill slope (Kuncha formation); 7: Boundary for the river functional flooding space; 8: Terrace edge; 9: Edge fall and river-bank collapse; 10: Tree; 11: Bush; 12: Motor road; 13: Irrigation dam weir (headworks); 14: Talus (debris fan); 15: Foot path ; 16: Ground elevation in m; 17: Building; 18: Kaseri (Laltin) Bazzar; 19: Shanti Tole; 20: Seti Irrigation dam. (b) View of Shanti Tole slum area, located to the east of Kaseri (Laltin) Bazzar (Photo by N. Gurung, 25 July 2020). 1: Kaseri (Laltin) Bazzar; 2: Shanti Tole; 3: Seti irrigation dam. The white dotted line is the boundary for the river functional space. 

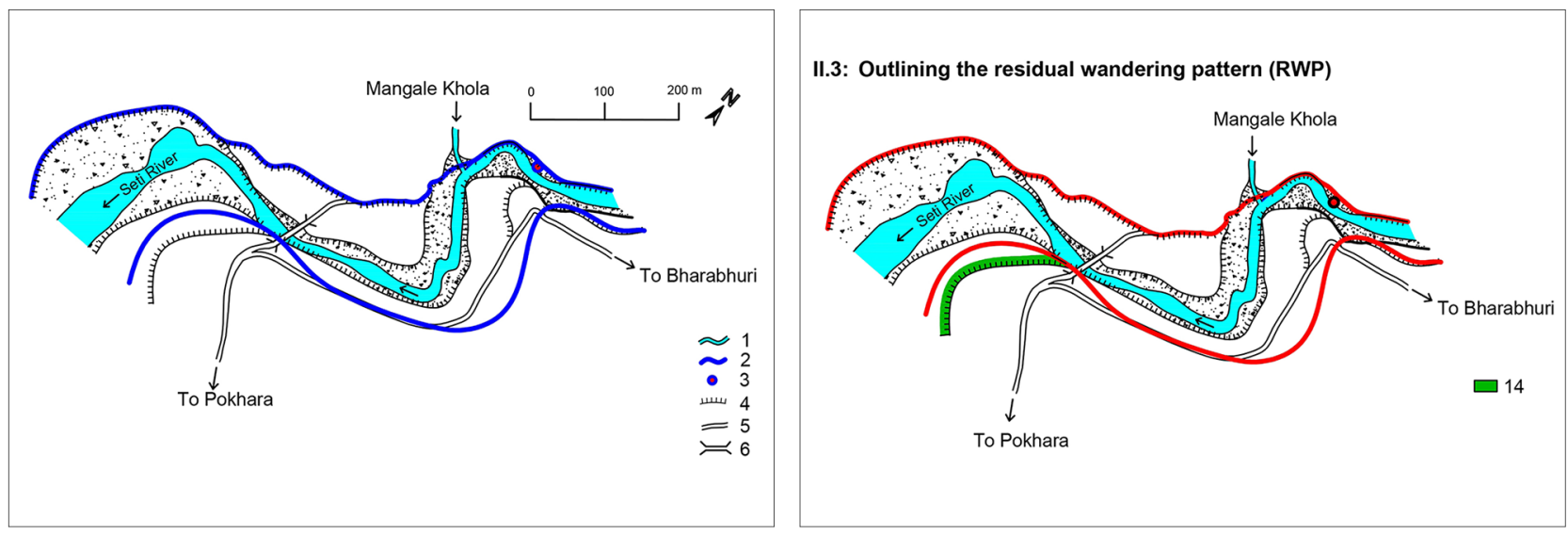

STEP II: OUTLINING THE FUNCTIONAL LOODING AREA (FFA)

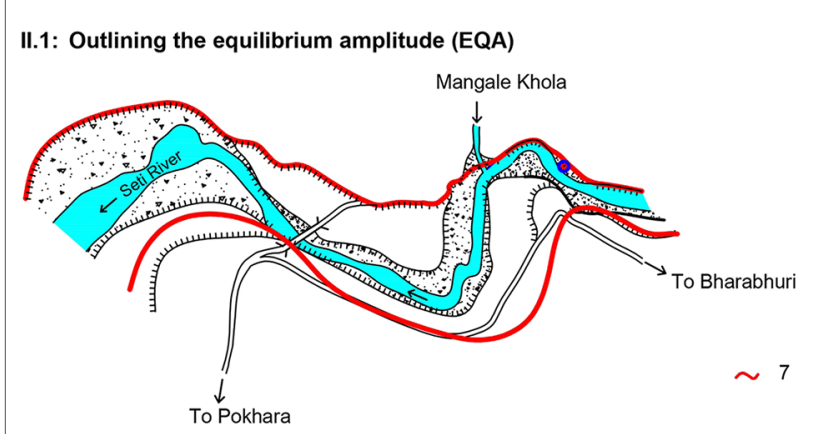

II.4: Outlining the potential erodible zones for the next 50 years $\left(\mathrm{PER}_{50}\right)$
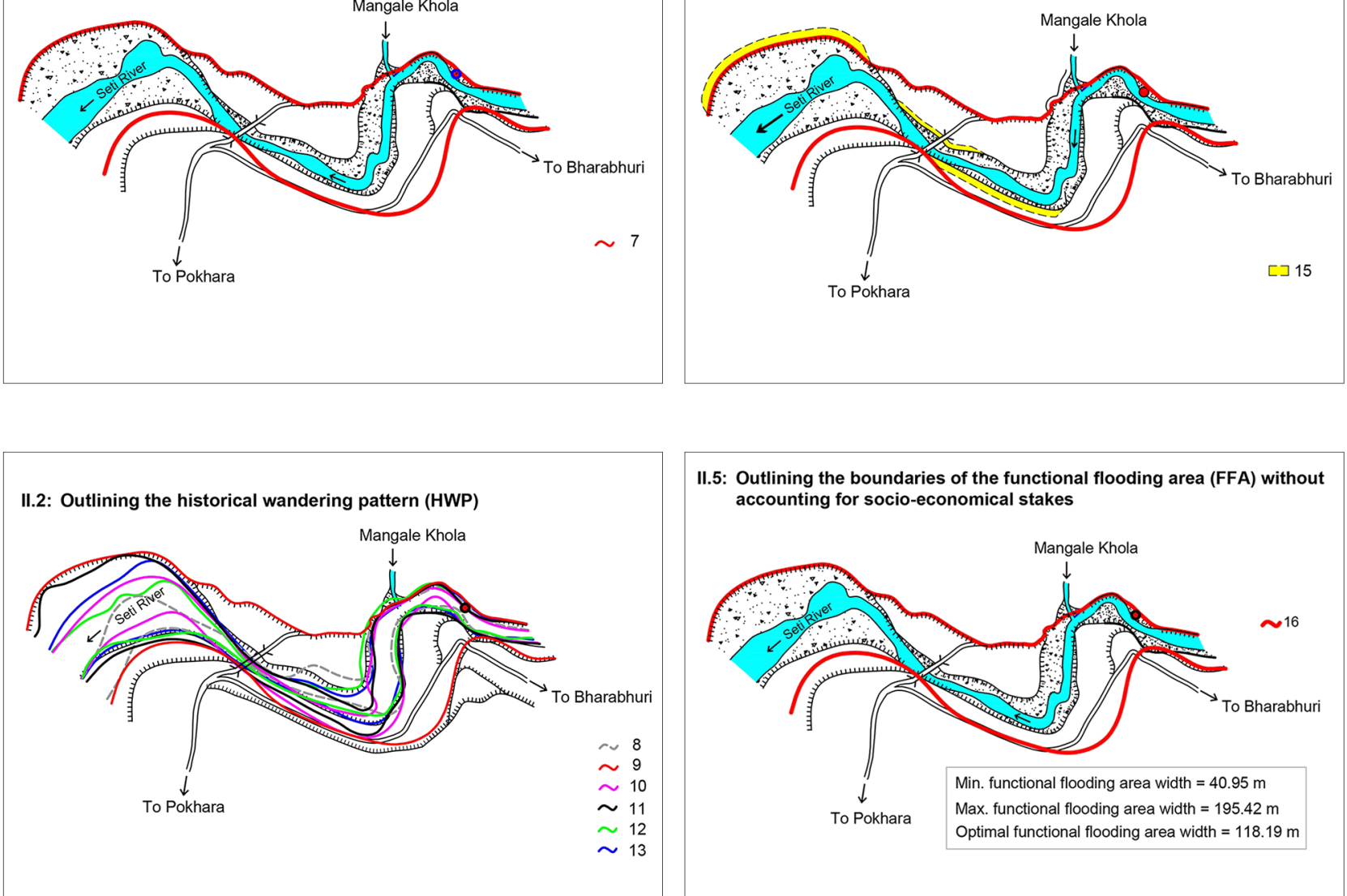

Fig. 11: The concept of "functional flooding area" (adapted from Malavoi et al., 1998 and Arnaud-Fassetta et al., 2009) applied to the Seti River at Khaarpaani Tatopani [site 5, Fig. 1]. 1: Present channel (2020); 2: Boundary of maximum flooding area; 3: Natural hot-spring; 4: Terrace edge; 5: Motor road; 6: Motor bridge; 7: Boundary of the theoretical amplitude $=$ active channel of the >80-year flood (2012); 8: 2011 channel; 9: 2012 channel; 10: 2014 channel; 11: 2016 channel; 12: 2017 channel; 13: 2020 channel; 14: Bank protection (gabions); 15: Potential erodible zone; 16: Boundary of the functional flooding area (FFA) without accounting for socio-economical stakes. Also see Fig. 10 (a) for the hydro-geomorphological map with the FFA, which can be outlined from steps as shown above. 

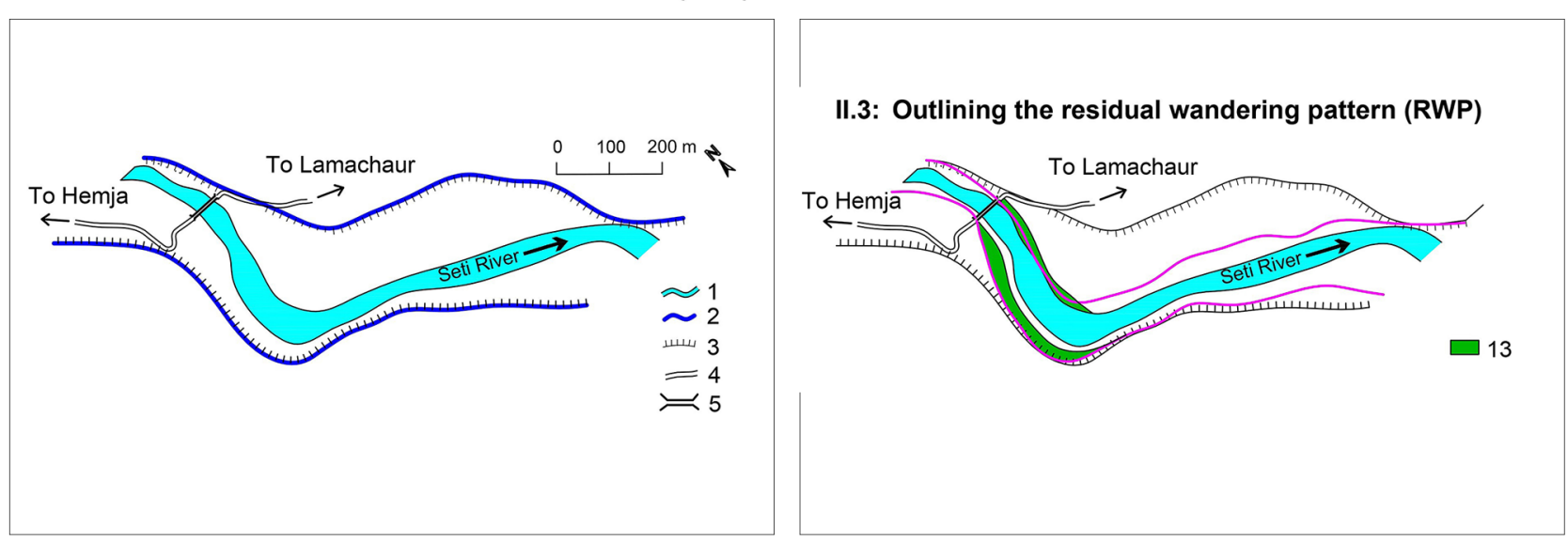

STEP II: OUTLINING THE FUNCTIONAL LOODING AREA (FFA)
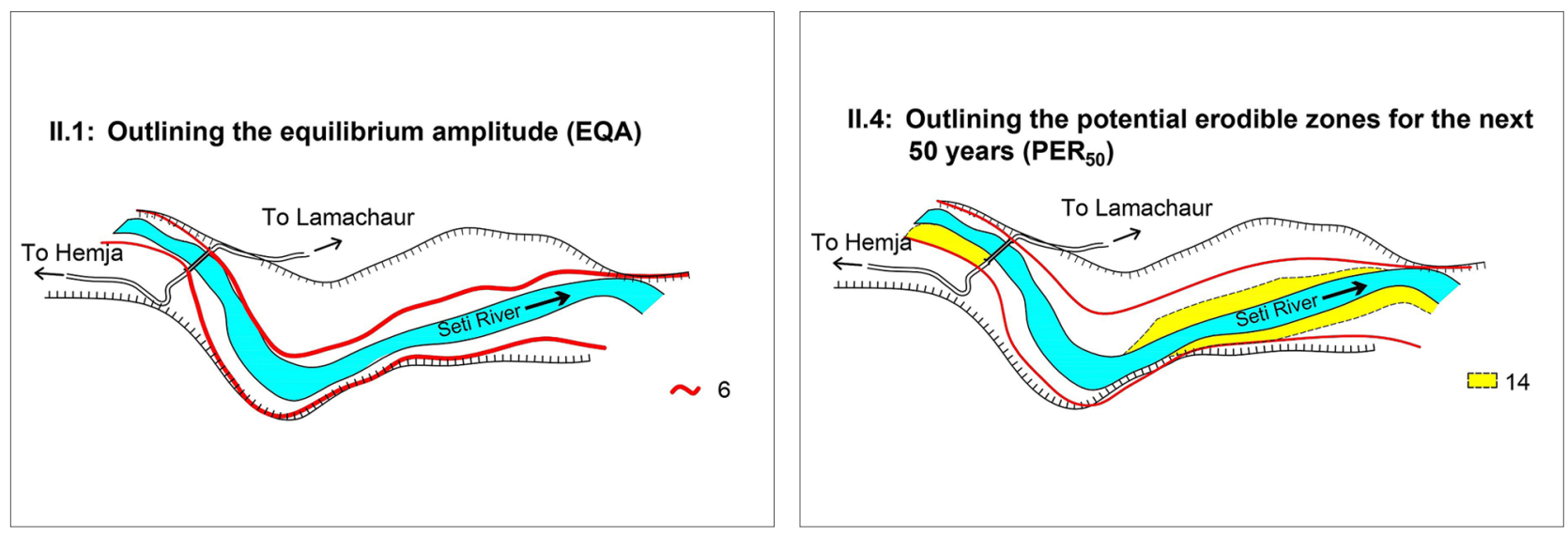

II.2: Outlining the historical wandering pattern (HWP)
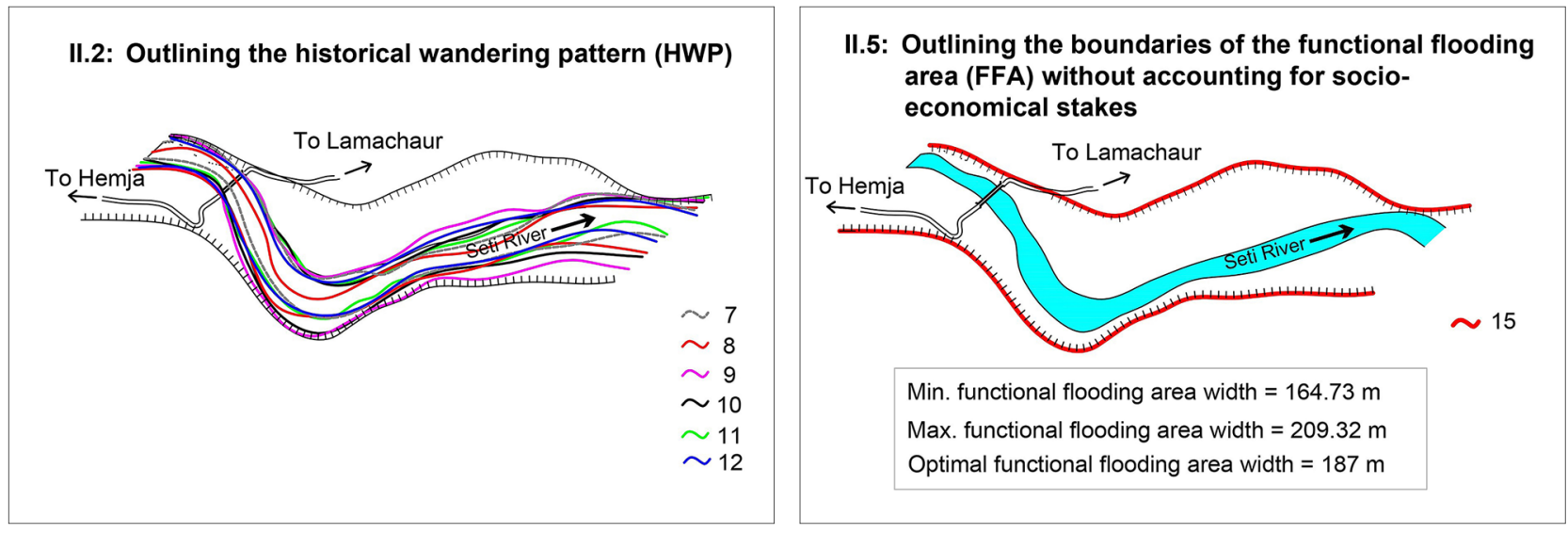

Fig. 12: The concept of "functional flooding area" (adapted from Malavoi et al., 1998 and Arnaud-Fassetta et al., 2009) applied to the Seti River at Masina Bagar and Upallo Gosti [site 9, Fig. 1]. 1: Present channel (2020); 2: Boundary of maximum flooding area; 3: Terrace edge; 4: Motor road; 5: Motor bridge; 6: Boundary of the theoretical amplitude $=$ active channel of the >80-year flood (2012); 7: 2004 channel; 8: 2008 channel; 9: 2012 channel; 10: 2014 channel; 11: 2018 channel; 12: 2020 channel; 13: Bank protection (gabions); 14: Potential erodible zone; 15: Boundary of the functional flooding area (FFA) without accounting for socio-economical stakes. Also see Fig. 12 for the hydro-geomorphological map with the FFA, which can be outlined from steps as shown above. 

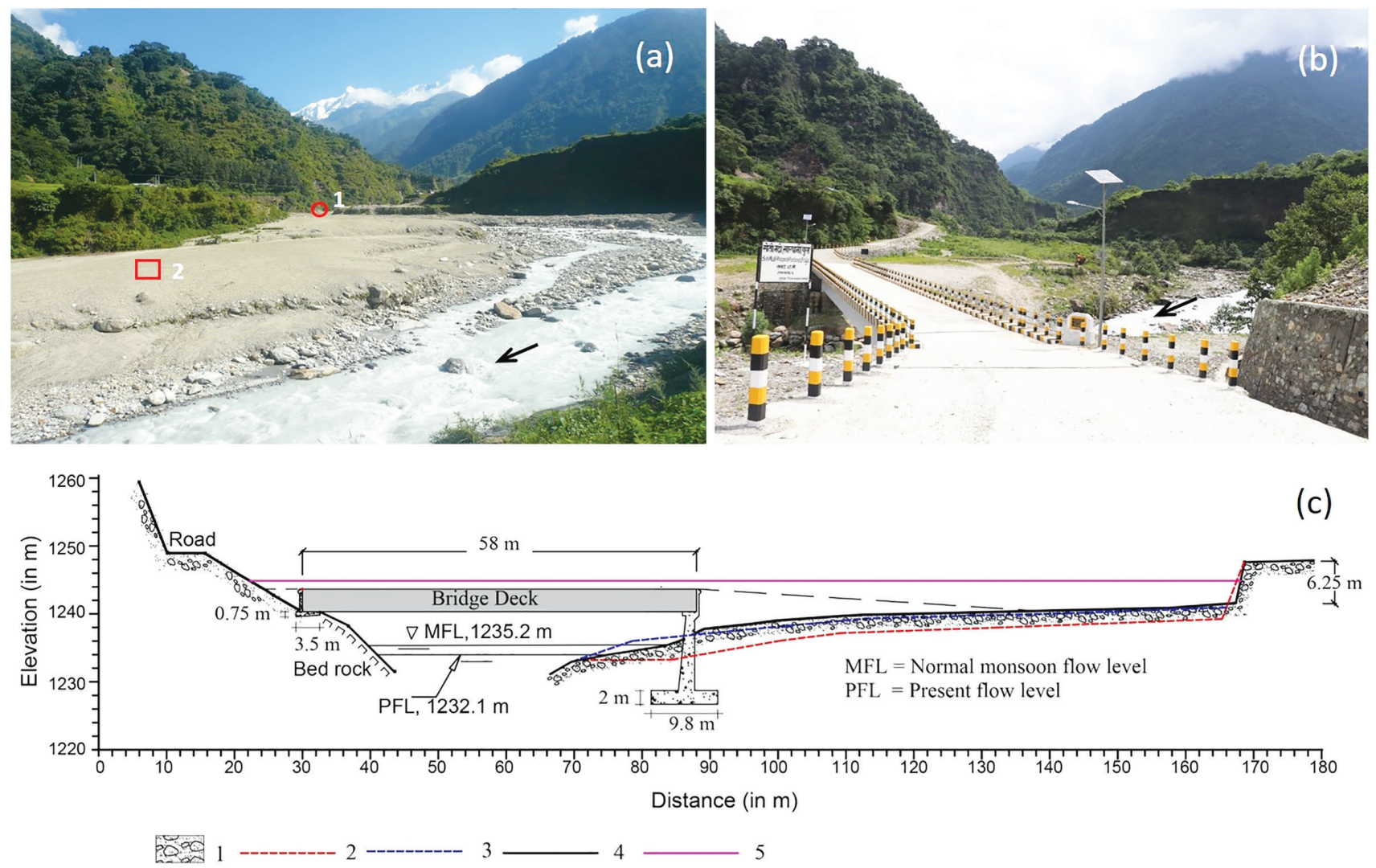

Fig. 13: View of Khaarpaani Tatopani [site 5, Fig. 1]. (a) Just after the 2012 Seti River flash flood (Photo by M. Fort, 23 September, 2012). 1. Location of natural hot spring; 2. Location of right bank abutment of the newly built 58-m long Seti River motorable bridge. The motorable bridge was built in 2020. (b) 8 years later (Photo by N. Gurung, 4 July, 2020). Note that the road, bridge and dykes have been built on the floodplain within the river functional flooding space as outlined in Fig. 7 and 11. (c) Cross-sections measured across the Seti River where motorable bridge is built (before and after the 2012 flood, and 2020). The bridge has been built without considering the high-flood level of 2012. Note that the 2012 high-flood level was measured above the newly built motorable bridge. 1: River bed deposit; 2: River profile before 2012 Seti flood; 3: River profile after 2012 Seti flood; 4: River profile of December 2020; 5: HFL (Highest Flow Level) during 2012 Seti flood.
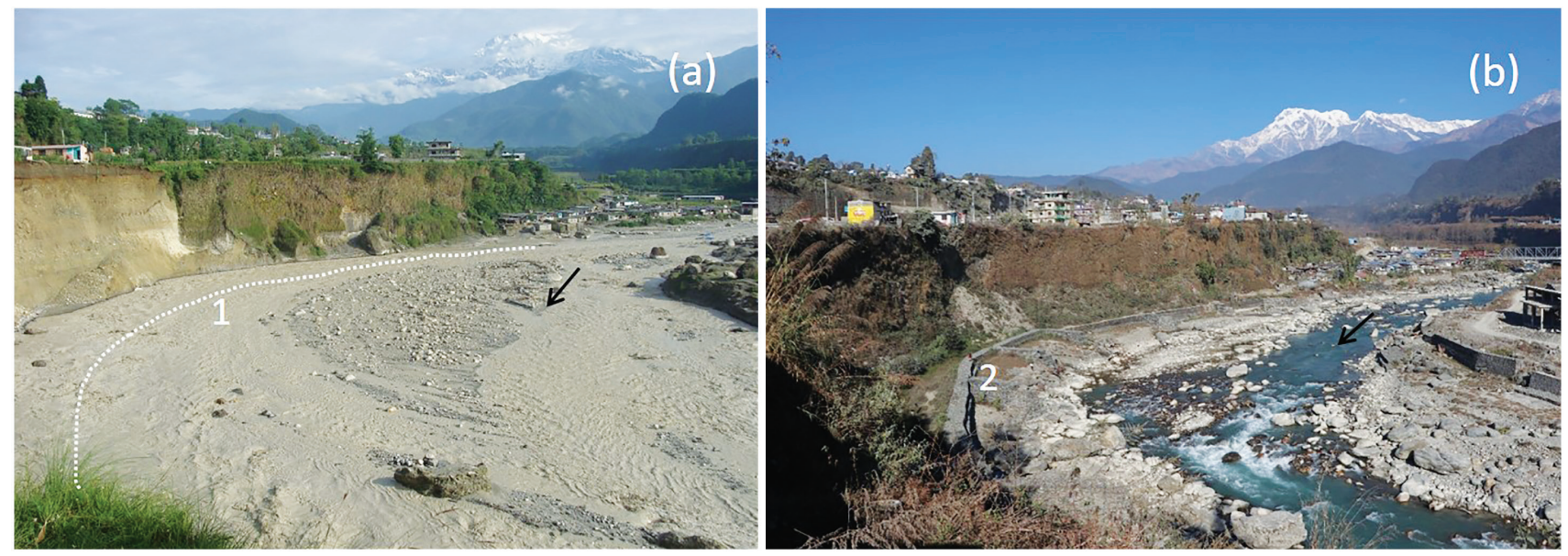

Fig. 14: Drinking water pipe for Pokhara city built in the floodplain to the east of Masina Bagar and across Upallo Gosti. (a) After the 2012 Seti flash flood (Photo by N. Gurung, 18 June 2012). The flood had completely washed away water pipes. The dotted line (depicted by 1 ) shows the water pipe line for Pokhara city. (b) Rebuilt of water pipe line for Pokhara city at the same place that was flooded in 2012 (Photo by N. Gurung, 6 January 2021). The gabion protection works (2) seem to work only for normal floods and the pipe line is vulnerable to for high floods. 


\section{Change on River Cross-Sections}

Results from the comparison of river cross-sections at five locations after the 2012 flood, i.e., between the period from 2013 to 2020 (Fig. 15) show that there was more erosion than deposition (Table 6) by monsoon floods $\left(16,400 \pm 1,640 \mathrm{~m}^{3}\right.$ vs. 3,900 \pm 390 $\left.\mathrm{m}^{3}\right)$ contrary to the 2012 Seti flood where there was more deposition than erosion. This seems to be valid because (i) the Seti River is progressively re-adjusting its long profile, and (ii) sand mining is taking place haphazardly at many places along the Seti River, thus accelerating the erosion process.

\section{Land-use and land-cover change (LULCC)}

According to the LULC maps of the Seti catchment including Pokhara valley (Fig. 16), the LULC has changed significantly from 1996 to 2020 . The significant change was observed on urban / built-up area (Table 7) : from 1996 to 2013 (17 years), it has increased by $245 \%$ from $13.2 \mathrm{~km}^{2}$ to $45.5 \mathrm{~km}^{2}$; from 2013 to 2020 ( 7 years), it has increased by $47 \%$ from $45.5 \mathrm{~km}^{2}$ to $66.7 \mathrm{~km}^{2}$; from 1996 to 2020 (24 years), it has increased by $405 \%$ from $13.2 \mathrm{~km}^{2}$ to $66.7 \mathrm{~km}^{2}$. This confirms a rapid urbanisation in Pokhara valley and its surroundings, mainly due to the construction of housing and infrastructures. The high rate of migration and population growth could have directly contributed to the rapid urban growth. In contrast, all other land uses (water body, open field, forest cover, sandy area, cultivated land and barren land) have significantly decreased during the period $1996-2020$ (Table 7).

The analysis of the LULC maps of four specific sites i.e. (i) Khaarpaani Tatopani, (ii) Mardi Dovan, (iii) Masina Bagar, Upallo Gosti and Tallo Gosti and (iv) Kaseri Bazzar and Shanti Tole (Fig. 17 to 20), confirms the significant increase observed on urban / built-up area. From 2004 to 2013 (9 years), the urban/ builtup area has increased by $28.07 \%$ for Mardi Dovan, $112.37 \%$ for Masina Bagar, Upallo Gosti, Tallo Gosti, and $125.20 \%$ for Kaseri Bazzar and Shanti Tole, but is reduced by $68.68 \%$ for Khaarpaani Tatopani (Table 8 a to d), a reduction attributed to the 2012 Seti flash flood that had completely wiped out houses at Khaarpaani Tatopani. Similarly for the period from 2013 to 2021 (8 years), the urban/built-up area has increased by $367.44 \%$ for Khaarpaani Tatopani, $144.87 \%$ for Mardi Dovan, $118.15 \%$ for Masina Bagar, Upallo Gosti, Tallo Gosti, and 66\% for Kaseri Bazzar and Shanti Tole (Table 8 a to d). This shows a high encroachment by many newly built dwellings and infrastructures over the floodplains along the Seti valley where flood risk is very high.

Table 5: Result from the comparison of cross-sections at five prominent places to assess the impact before and after the 2012 Seti flood (Fig. 15).

\begin{tabular}{ccccccc}
\hline \multirow{2}{*}{ Section } & \multicolumn{3}{c}{ Erosion after the 2012 Seti flood } & \multicolumn{3}{c}{ Deposition after the 2012 Seti flood } \\
\cline { 2 - 6 } & Area (in $\left.\mathrm{m}^{2}\right)$ & Length (in m) & Volume (in $\left.\mathrm{m}^{3}\right)$ & $\begin{array}{c}\text { Area } \\
\left({\left.\text { in } \mathrm{m}^{2}\right)}^{2}\right.\end{array}$ & Length (in m) & Volume (in m $)^{3}$ \\
\hline A & 61.2 & 100 & $6120 \pm 612$ & - & - & - \\
B & 25.2 & 100 & $2520 \pm 252$ & - & - & - \\
C & - & - & - & 200 & 100 & $20,000 \pm 2,000$ \\
D & 10 & 100 & $1000 \pm 100$ & 85.7 & 100 & $8570 \pm 857$ \\
E & 2.8 & 100 & $280 \pm 28$ & 55 & 100 & $5500 \pm 550$ \\
Total & 99.2 & 400 & $9920 \pm 992$ & 343.70 & 300 & $34,070 \pm 3,407$ \\
\hline
\end{tabular}

Table 6: Result from the comparison of cross-sections at five prominent places along Seti River to assess the aggradation and degradation from 2012 to 2020 (Fig. 15).

\begin{tabular}{|c|c|c|c|c|c|c|}
\hline \multirow[b]{2}{*}{ Section } & \multicolumn{3}{|c|}{ Erosion from 2012 to 2020} & \multicolumn{3}{|c|}{ Deposition from 2012 to 2020} \\
\hline & $\begin{array}{c}\text { Area } \\
\left({\left.\text { in } \mathrm{m}^{2}\right)}\right.\end{array}$ & Length (in $\mathrm{m}$ ) & Volume (in $\mathrm{m}^{3}$ ) & Area $\left(\right.$ in $\left.\mathrm{m}^{2}\right)$ & $\begin{array}{l}\text { Length } \\
\text { (in m) }\end{array}$ & Volume (in $\mathrm{m}^{3}$ ) \\
\hline A & 5 & 100 & $500 \pm 50$ & 20.80 & 100 & $2080 \pm 208$ \\
\hline B & 6 & 100 & $600 \pm 60$ & 18.20 & 100 & $1820 \pm 180$ \\
\hline $\mathrm{C}$ & 12 & 100 & $1200 \pm 120$ & - & - & - \\
\hline $\mathrm{D}$ & 61 & 100 & $6100 \pm 610$ & - & - & - \\
\hline $\mathrm{E}$ & 80 & 100 & $8000 \pm 800$ & - & - & - \\
\hline Total & 164 & 500 & $16,400 \pm 1,640$ & 39 & 200 & $3900 \pm 390$ \\
\hline
\end{tabular}




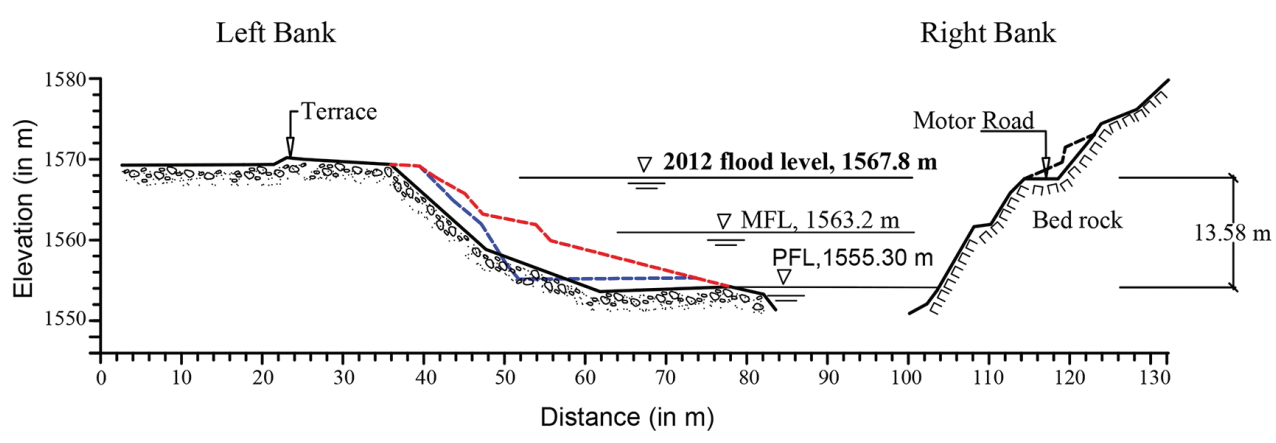

(a)

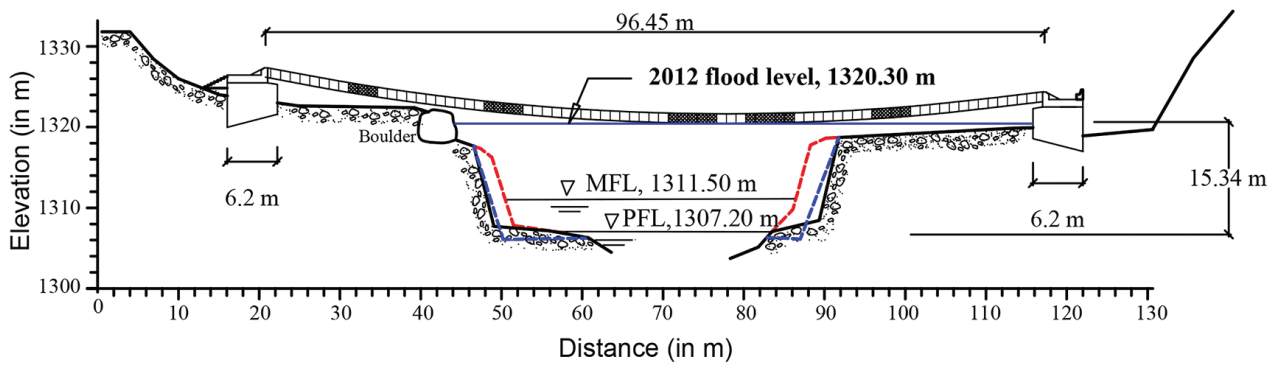

(b)
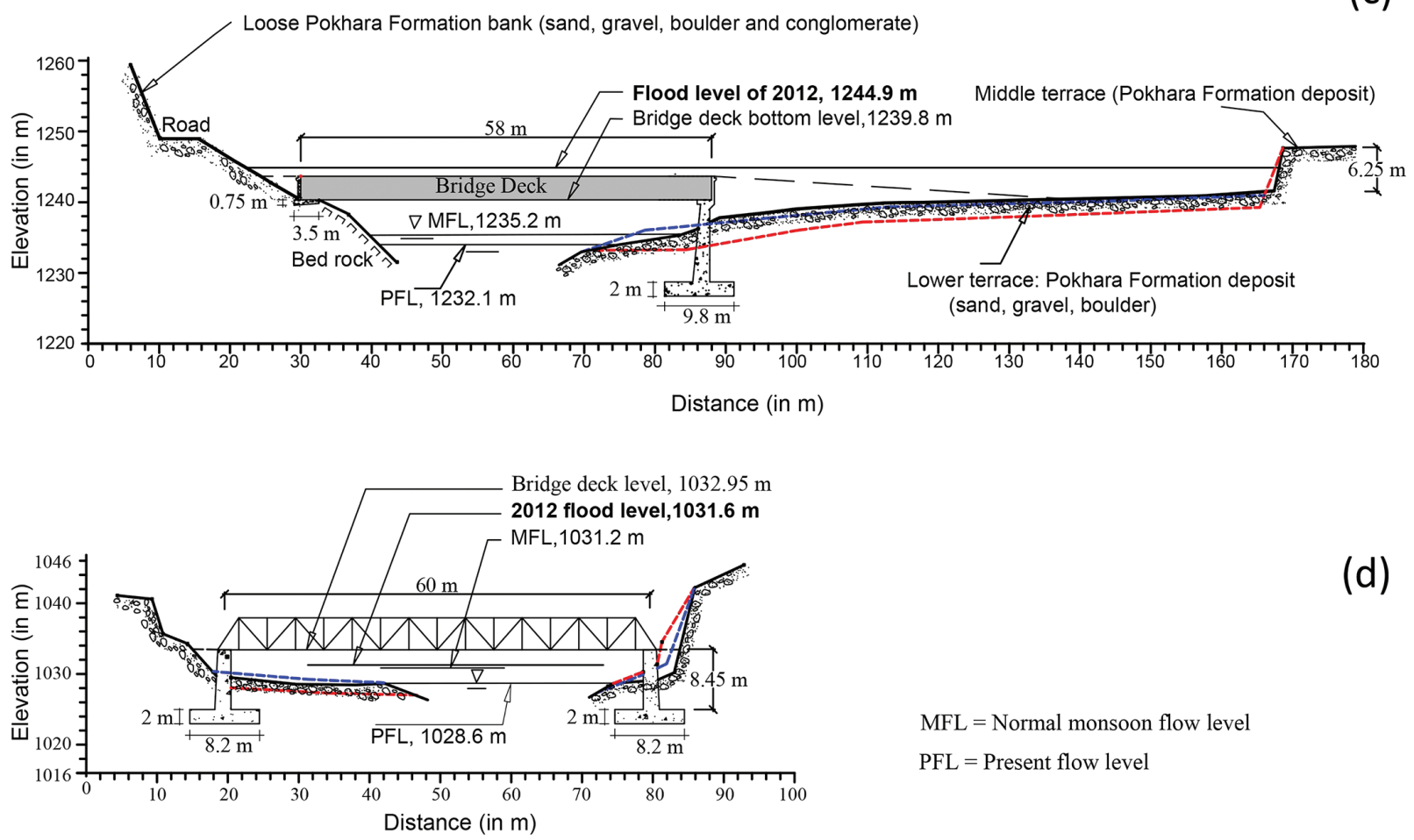

(d)

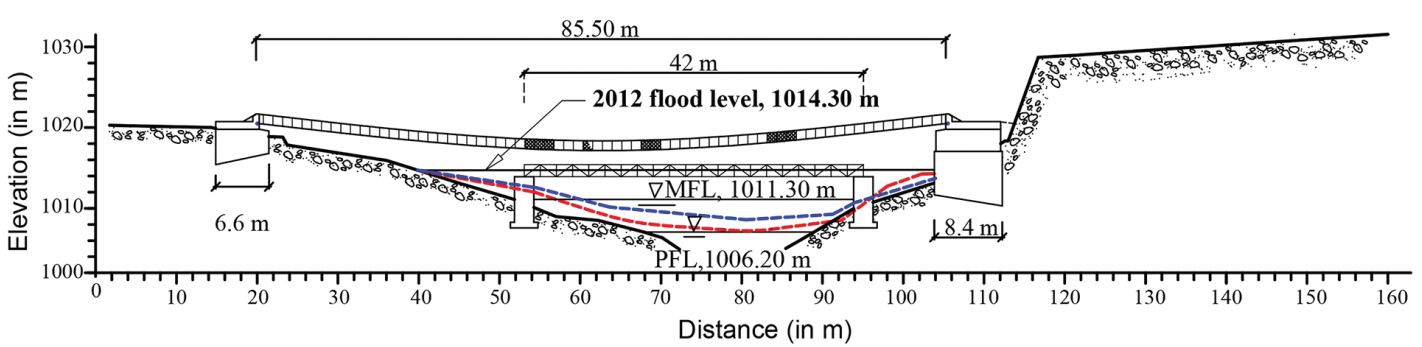

(e)

政圈 1

Fig. 15: Comparison of cross-sections of the Seti River at five locations before and after the 2012 flood and present (2020). a. Saadal; b. Bharabhuri Bagar (Karuwa); c. Khaarpaani Tatopani motorable bridge; d. Mardi Dovan motorable bridge; e. Hemja Bensi suspended bridge site. 1: Riverbed deposit (sand, gravel and boulder); 2: River profile before 2012 Seti flood; 3: River profile after the 2012 Seti flood; 4: River profile of December 2020. All river profiles before the 2012 Seti flood were provided by Kadoorie Agricultural Aid Association except for Khaarpaani Tatopani and Mardi Dovan (Department of Roads). The river profiles after the 2012 Seti flood and 2020 were measured by authors. 
Riverbank Settlements and Geo-hazards prone Areas along the Seti Valley

The riverside dwellings have been found to be on increasing trend. There is no official document yet about when people actually started to live in floodplains along the Seti riverbanks. However, based on the interviews with the local people living in these riverbank slum settlements, the first slum settlement in Pokhara started in Kaseri (Laltin) Bazzar in 1980 (40 years ago). The process then expanded to Saadal, Ebang [Fig. 1 (3)], Masina Bagar, Upallo and Tallo Gosti [Fig. 1 (9)], Shanti Tole [Fig. 1 (10)], and
Ramghat [Fig. 1 (13)]. Shanti Tole [Fig. 10 (b)], located to the east of Kaseri (Laltin) Bazzar, is known to be the latest slum settlement that sprung up on the Seti riverbank. According to locals, Shanti Tole slum started developing with few houses in 2005 during the peak Maoist insurgency period $(1996-2006)$ in Nepal. At that time, law and order situation was very weak, people had taken advantage of the situation, and over the years expanded to block the very course of the river; there are as many as 180 houses in Shanti Tole alone. The hydro-torrential hazard places along the Seti valley from the studied area, are presented in Table 9.
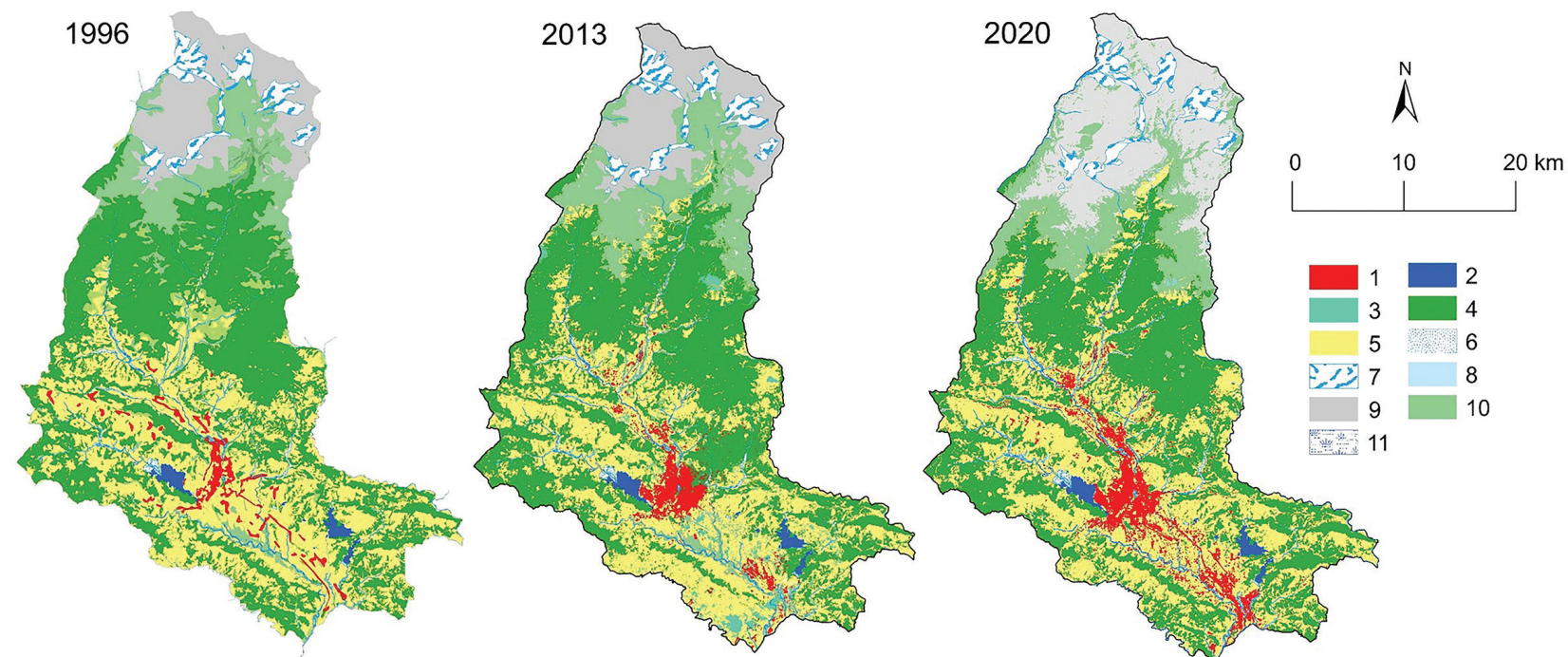

Fig. 16: Land-use and land-cover (LULC) map of the Seti catchment including Pokhara valley for 1996, 2013 and 2020. The 1996 map was prepared based on the topographic survey map of 1996 (scale 1:25,000) and the 2013 and 2020 maps were prepared based on Landsat 8 satellite images of 30-m resolution. 1: Urban/Built-up; 2: Water body; 3: Open field; 3: Forest cover; 5: Cultivated land; 6: Sandy area; 7: Glacier; 8: Snow cover; 9: Barren land; 10: Grass land; 11: Swamp area.

Table 7: Land-use and land-cover change (LULCC) between 1996 and 2020.

\begin{tabular}{|c|c|c|c|c|c|c|c|c|c|c|c|c|}
\hline \multirow{3}{*}{ Fields } & \multirow{2}{*}{\multicolumn{2}{|c|}{$\begin{array}{c}\text { Land cover } \\
(1996)\end{array}$}} & \multirow{2}{*}{\multicolumn{2}{|c|}{$\begin{array}{c}\text { Land cover } \\
(2013)\end{array}$}} & \multirow{2}{*}{\multicolumn{2}{|c|}{$\begin{array}{c}\text { Land cover } \\
(2020)\end{array}$}} & \multicolumn{6}{|c|}{ Land-use and land-cover change (LULCC) } \\
\hline & & & & & & & \multirow{2}{*}{$\begin{array}{l}1996- \\
2013 \\
\text { (in } \\
\mathrm{km}^{2} \text { ) }\end{array}$} & \multirow{2}{*}{$\begin{array}{l}1996 \\
-2013 \\
(\text { in \%) }\end{array}$} & \multirow{2}{*}{$\begin{array}{l}2013- \\
2020 \\
(\text { in } \\
\mathrm{km}^{2} \text { ) }\end{array}$} & \multirow{2}{*}{$\begin{array}{l}2013 \\
-2020 \\
\text { (in \%) }\end{array}$} & \multirow{2}{*}{$\begin{array}{c}1996- \\
2020 \text { (in } \\
\mathrm{km}^{2} \text { ) }\end{array}$} & \multirow{2}{*}{$\begin{array}{c}1996 \\
-2020 \\
\text { (in \%) }\end{array}$} \\
\hline & in $\mathrm{km}^{2}$ & in $\%$ & in $\mathrm{km}^{2}$ & in $\%$ & in $\mathrm{km}^{2}$ & in $\%$ & & & & & & \\
\hline $\begin{array}{l}\text { Urban / } \\
\text { Built-up }\end{array}$ & 13.2 & 1.1 & 45.5 & 3.9 & 66.7 & 5.7 & 32.3 & +244.7 & 21.2 & +46.6 & 53.5 & +405.3 \\
\hline Water body & 16.1 & 1.4 & 13.8 & 1.2 & 14.8 & 1.3 & -2.3 & -14.3 & 1.0 & -10.8 & -1.3 & -8.1 \\
\hline Open field & 4.9 & 0.4 & 2.6 & 0.2 & 4.7 & 0.4 & -2.3 & -47.0 & 2.1 & +80.8 & -0.2 & -4.3 \\
\hline Forest cover & 462.6 & 39.7 & 434.0 & 37.2 & 400.0 & 34.3 & -28.6 & -6.2 & -34.0 & -7.8 & -62.6 & -13.5 \\
\hline $\begin{array}{l}\text { Cultivate-d } \\
\text { land }\end{array}$ & 365.6 & 31.4 & 359.0 & 30.8 & 345.1 & 29.6 & -6.6 & -1.8 & -13.9 & -3.9 & -20.5 & -5.6 \\
\hline Sandy area & 16.7 & 1.4 & 7.6 & 0.7 & 8.1 & 0.7 & -9.1 & -54.5 & 0.5 & +6.6 & -8.6 & -51.5 \\
\hline Glacier & 36.1 & 3.1 & 35.1 & 3.0 & 36.1 & 3.1 & -1.0 & -2.8 & 1.0 & +2.9 & 0.0 & 0.0 \\
\hline Snow cover & 29.2 & 2.5 & 36.2 & 3.1 & 83.6 & 7.2 & 7.0 & +24.0 & 47.4 & +130.9 & 54.4 & +186.4 \\
\hline Barren land & 104.5 & 9.0 & 102.9 & 8.8 & 56.6 & 4.9 & -1.6 & -1.5 & -46.3 & -45.0 & -47.9 & -45.9 \\
\hline Grass land & 114.9 & 9.9 & 124.8 & 10.7 & 132.9 & 11.4 & 9.9 & +8.6 & 8.1 & +6.5 & 18.0 & +15.6 \\
\hline Swamp area & 1.4 & 0.1 & 3.6 & 0.3 & 16.5 & 1.4 & 2.2 & +161.7 & 12.9 & +358.3 & 15.1 & $+1,099.5$ \\
\hline Total & 1165.1 & 100 & 1165.1 & 100 & 1165.1 & 100 & & & & & & \\
\hline
\end{tabular}



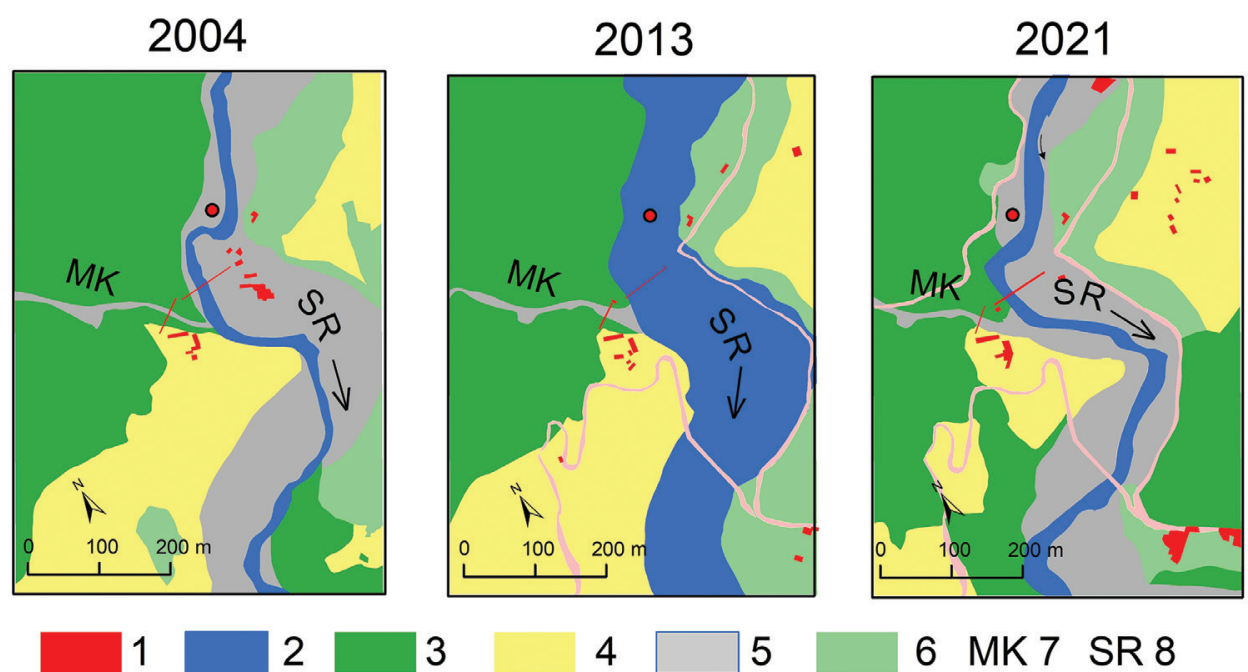

4

\section{5}

6 MK 7 SR 8

Fig. 17: Land-use and land-cover map of Khaarpaani Tatopani for 2004, 2013, and 2021 [site 5, Fig. 1]. 1: Urban/ Built-up; 2: Water body; 3: Forest cover; 4: Cultivated land; 5: Flood plain; 6: Open field; 7: Mangale Khola (MK); 8: Seti River (SR). All base maps were sourced from Google Earth. Dates are 20.11.2004 for 2004, 06.10.2013 for 2013, and 10.01.2021 for 2021.
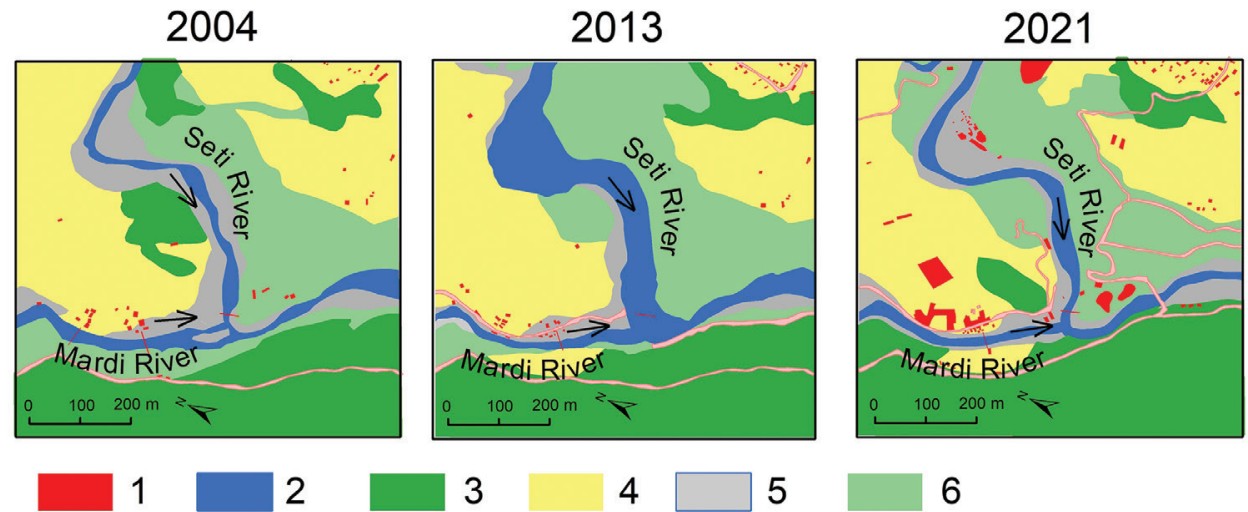

3

4

5

6

Fig. 18: Land-use and land-cover map of Mardi Dovan (confluence Seti River/Mardi River) for 2004, 2013, and 2021 [site 7, Fig. 1]. 1: Urban/Built-up; 2: Water body; 3: Forest cover; 4: Cultivated land; 5: Flood plain; 6: Open field. All base maps were sourced from Google Earth. Dates are 20.11.2004 for 2004, 10.12.2013 for 2013 and 10.01.2021 for 2021.
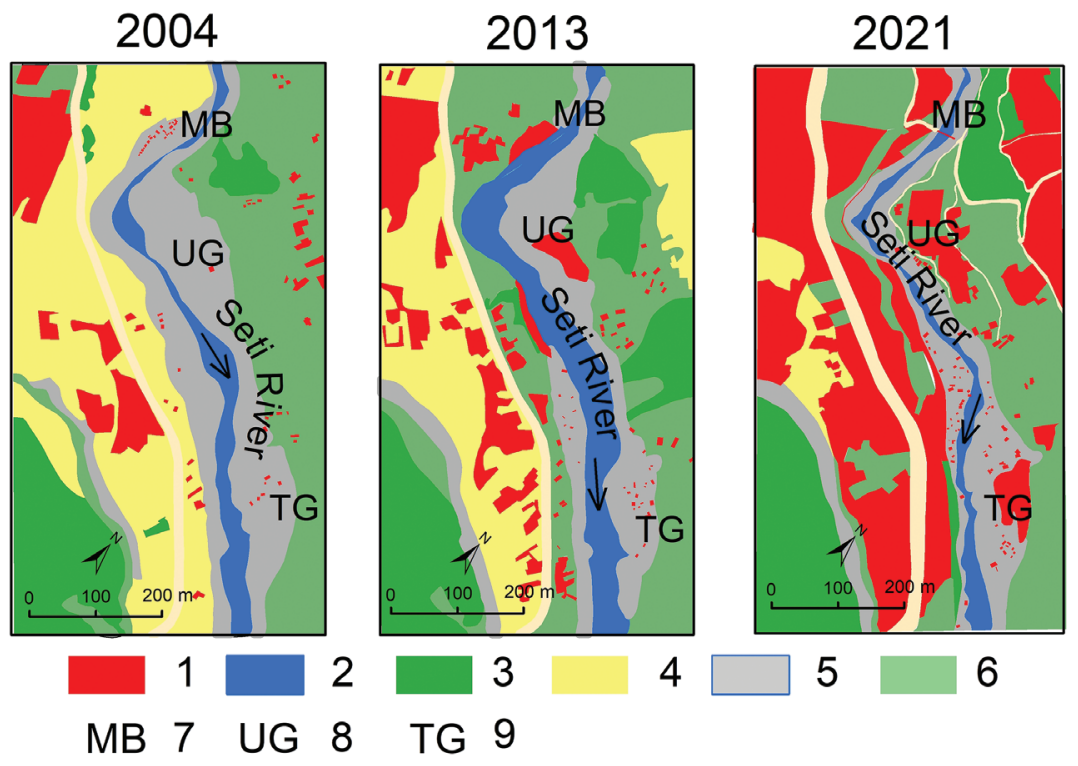

Fig. 19: Land-use and land-cover map of Masina Bagar (MB), Upallo Gosti (UG) and Tallo Gosti (TG) for 2004, 2013, and 2021 [site 9, Fig. 1]. 1: Urban/Built-up; 2: Water body; 3: Forest cover; 4: Cultivated land; 5: Flood plain; 6: Open field; 7: Masina Bagar (MB); 8: Upallo Gosti (UG); 9: Tallo Gosti (TG). All base maps were sourced from Google Earth. Dates are 20.11.2004 for 2004, 06.10.2013 for 2013, and 10.01.2021 for 2021. 
2004

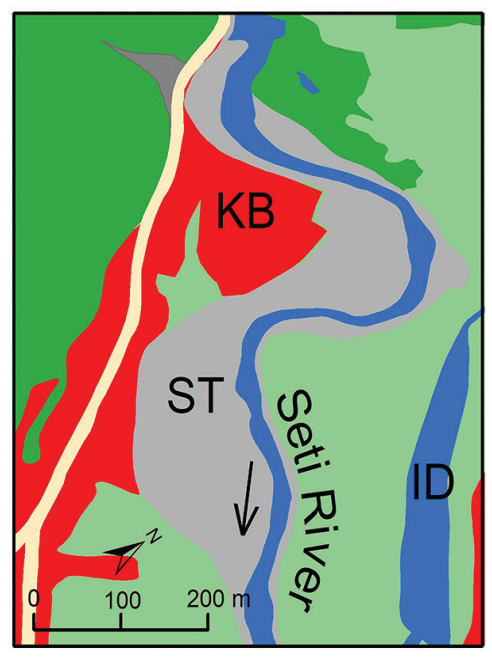

2013

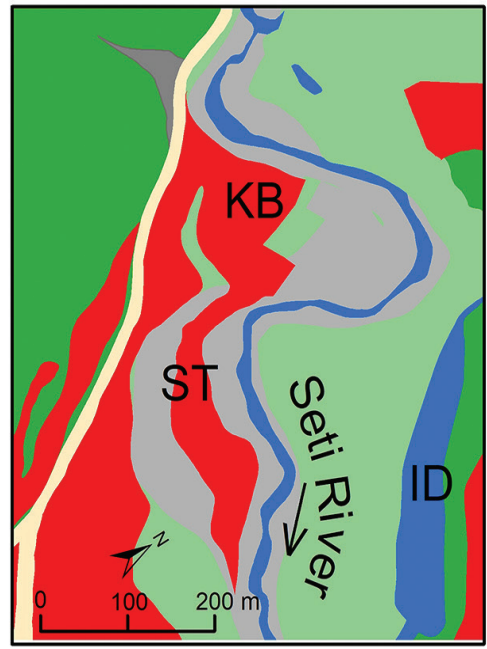

2021

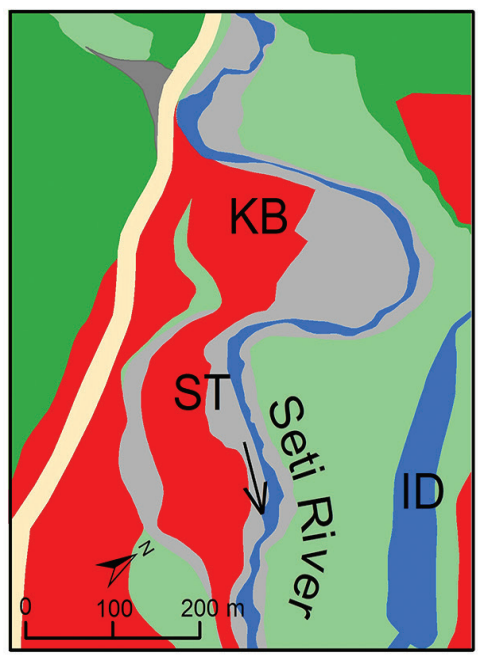

5

\section{$\begin{array}{llllll}\mathrm{KB} & 7 & \mathrm{ST} & 8 & \text { ID } & 9\end{array}$}

Fig. 20: Land-use and land-cover map of Kaseri Bazzar and Shanti Tole for 2004, 2013, and 2021 [site 10, Fig. 1]. 1: Urban/Built-up; 2: Water body; 3: Forest cover; 4: Open field; 5: Flood plain; 6: Debris fan; 7: Kaseri Bazzar (KB); 8: Shanti Tole (ST); 9: Irrigation dam (ID). All base maps were sourced from Google Earth. Dates are 21.11.2004 for 2004, 10.01.2013 for 2013, and 10.01.2021 for 2021.

Table 7: Land-use and land-cover change (LULCC) between 1996 and 2020.

\begin{tabular}{|c|c|c|c|c|c|c|c|c|c|c|c|c|}
\hline \multirow[t]{3}{*}{ Fields } & \multirow{2}{*}{\multicolumn{2}{|c|}{$\begin{array}{c}\text { Land cover } \\
(1996)\end{array}$}} & \multirow{2}{*}{\multicolumn{2}{|c|}{$\begin{array}{c}\text { Land cover } \\
(2013) \\
\text { Area }\end{array}$}} & \multirow{2}{*}{\multicolumn{2}{|c|}{$\begin{array}{c}\text { Land cover } \\
(2020)\end{array}$}} & \multicolumn{6}{|c|}{ Land-use and land-cover change (LULCC) } \\
\hline & & & & & & & \multirow{2}{*}{$\begin{array}{c}\text { 1996- } \\
2013 \\
\left(\text { in } \mathrm{km}^{2}\right)\end{array}$} & \multirow{2}{*}{$\begin{array}{c}1996 \\
-2013 \\
(\text { in \%) }\end{array}$} & \multirow{2}{*}{$\begin{array}{c}2013- \\
2020 \\
\left(\mathrm{in} \mathrm{km}^{2}\right)\end{array}$} & \multirow{2}{*}{$\begin{array}{c}2013 \\
-2020 \\
(\text { in \%) }\end{array}$} & \multirow{2}{*}{$\begin{array}{l}1996- \\
2020 \text { (in } \\
\mathrm{km}^{2} \text { ) }\end{array}$} & \multirow{2}{*}{$\begin{array}{c}1996 \\
-2020 \\
\text { (in \%) }\end{array}$} \\
\hline & in & in $\%$ & in $\mathrm{km}^{2}$ & in $\%$ & in $\mathrm{km}^{2}$ & in $\%$ & & & & & & \\
\hline $\begin{array}{l}\text { Urban / } \\
\text { Built-up }\end{array}$ & 13.2 & 1.1 & 45.5 & 3.9 & 66.7 & 5.7 & 32.3 & +244.7 & 21.2 & +46.6 & 53.5 & +405.3 \\
\hline Water body & 16.1 & 1.4 & 13.8 & 1.2 & 14.8 & 1.3 & -2.3 & -14.3 & 1.0 & -10.8 & -1.3 & -8.1 \\
\hline Open field & 4.9 & 0.4 & 2.6 & 0.2 & 4.7 & 0.4 & -2.3 & -47.0 & 2.1 & +80.8 & -0.2 & -4.3 \\
\hline Forest cover & 462.6 & 39.7 & 434.0 & 37.2 & 400.0 & 34.3 & -28.6 & -6.2 & -34.0 & -7.8 & -62.6 & -13.5 \\
\hline $\begin{array}{c}\text { Cultivate-d } \\
\text { land }\end{array}$ & 365.6 & 31.4 & 359.0 & 30.8 & 345.1 & 29.6 & -6.6 & -1.8 & -13.9 & -3.9 & -20.5 & -5.6 \\
\hline Sandy area & 16.7 & 1.4 & 7.6 & 0.7 & 8.1 & 0.7 & -9.1 & -54.5 & 0.5 & +6.6 & -8.6 & -51.5 \\
\hline Glacier & 36.1 & 3.1 & 35.1 & 3.0 & 36.1 & 3.1 & -1.0 & -2.8 & 1.0 & +2.9 & 0.0 & 0.0 \\
\hline Snow cover & 29.2 & 2.5 & 36.2 & 3.1 & 83.6 & 7.2 & 7.0 & +24.0 & 47.4 & +130.9 & 54.4 & +186.4 \\
\hline Barren land & 104.5 & 9.0 & 102.9 & 8.8 & 56.6 & 4.9 & -1.6 & -1.5 & -46.3 & -45.0 & -47.9 & -45.9 \\
\hline Grass land & 114.9 & 9.9 & 124.8 & 10.7 & 132.9 & 11.4 & 9.9 & +8.6 & 8.1 & +6.5 & 18.0 & +15.6 \\
\hline Swamp area & 1.4 & 0.1 & 3.6 & 0.3 & 16.5 & 1.4 & 2.2 & +161.7 & 12.9 & +358.3 & 15.1 & $+1,099.5$ \\
\hline Total & 1165.1 & 100 & 1165.1 & 100 & 1165.1 & 100 & & & & & & \\
\hline
\end{tabular}


Table 8a: Land-use and land-cover change (LULCC) of Khaarpaani Tatopani between 2004 and 2021.

\begin{tabular}{|c|c|c|c|c|c|c|}
\hline \multicolumn{7}{|c|}{ Khaarpaani Tatopani } \\
\hline \multirow{2}{*}{ Fields } & \multirow{2}{*}{$\begin{array}{c}\text { Land cover } \\
(2004)\end{array}$} & \multirow{2}{*}{$\begin{array}{l}\text { Land cover } \\
\text { (2013) } \\
\text { Area in } \mathrm{m}^{2}\end{array}$} & \multirow{2}{*}{$\begin{array}{l}\text { Land cover } \\
\text { (2021) } \\
\text { Area in } \mathrm{m}^{2}\end{array}$} & \multicolumn{3}{|c|}{ LULC change (2004-2021) } \\
\hline & & & & $\begin{array}{l}\text { 2004-2013 } \\
\quad\left(\text { in } \mathrm{m}^{2} \text { ) }\right.\end{array}$ & $\begin{array}{l}2013-2021 \\
\quad\left(\text { in }^{2}\right)\end{array}$ & $\begin{array}{l}\text { 2004-2021 } \\
\quad\left(\text { in } \text { m }^{2}\right)\end{array}$ \\
\hline Urban/Built-up & 6130.7 & 1920.4 & 8976.5 & -4210.4 & 7056.1 & 2845.7 \\
\hline Water body & $14,800.0$ & $17,825.9$ & $21,500.0$ & 3025.9 & 3674.1 & 6700.0 \\
\hline Forest cover & $152,557.1$ & $128,259.6$ & $215,313.7$ & $-24,297.5$ & $87,054.1$ & $62,756.6$ \\
\hline Cultivated land & $92,273.9$ & $98,500.0$ & $53,687.3$ & 6226.1 & $-44,812.7$ & $-38,586.6$ \\
\hline Floodplain & $42,815.3$ & $83,967.0$ & $66,920.2$ & $41,151.7$ & $-17,046.9$ & $24,104.9$ \\
\hline Open field & $72,038.1$ & $50,142.3$ & $14,217.5$ & $-21,895.9$ & $-35,924.8$ & $-57,820.6$ \\
\hline Total & $380,615.1$ & $380,615.1$ & $380,615.1$ & & & \\
\hline \multirow{2}{*}{ Fields } & $\begin{array}{l}\text { Land cover } \\
(2004)\end{array}$ & $\begin{array}{l}\text { Land cover } \\
\quad(2013)\end{array}$ & $\begin{array}{l}\text { Land cover } \\
\text { (2021) }\end{array}$ & \multicolumn{3}{|c|}{ LULC change (2004-2021) } \\
\hline & Area in $\%$ & Area in $\%$ & Area in $\%$ & 2004-2013 (in \%) & $\begin{array}{c}\text { 2013-2021 } \\
\text { (in \%) }\end{array}$ & $\begin{array}{l}\text { 2004-2021 } \\
\text { (in \%) }\end{array}$ \\
\hline Urban/Built-up & 1.6 & 0.5 & 2.4 & -68.7 & +367.4 & +46.4 \\
\hline Water body & 3.9 & 4.7 & 5.6 & +20.5 & +20.6 & +45.3 \\
\hline Forest cover & 40.1 & 33.7 & 56.6 & -15.9 & +67.9 & +41.1 \\
\hline Cultivated land & 24.2 & 25.9 & 14.1 & +6.8 & -45.5 & -41.8 \\
\hline Floodplain & 11.2 & 22.1 & 17.6 & +96.1 & -20.3 & +56.3 \\
\hline Open field & 18.9 & 13.2 & 3.7 & -30.4 & -71.7 & -80.3 \\
\hline Total & 100 & 100 & 100 & & & \\
\hline
\end{tabular}

Table 8b: Land-use and land-cover change (LULCC) of Mardi Dovan between 2004 and 2021.

\begin{tabular}{|c|c|c|c|c|c|c|}
\hline \multicolumn{7}{|c|}{ Mardi Dovan } \\
\hline \multirow{2}{*}{ Fields } & $\begin{array}{l}\text { Land cover } \\
\quad(2004)\end{array}$ & $\begin{array}{l}\text { Land cover } \\
\text { (2013) }\end{array}$ & $\begin{array}{l}\text { Land cover } \\
\quad(2021)\end{array}$ & \multicolumn{3}{|c|}{ LULC change (2004-2021) } \\
\hline & Area in $\mathrm{m}^{2}$ & Area in $\mathrm{m}^{2}$ & Area in $\mathrm{m}^{2}$ & $\begin{array}{l}\text { 2004-2013 } \\
\quad\left(\text { in } \mathrm{m}^{2}\right)\end{array}$ & $\begin{array}{l}\text { 2013-2021 } \\
\quad\left(\text { in } \text { m }^{2}\right)\end{array}$ & $\begin{array}{l}\text { 2004-2021 } \\
\quad\left(\text { in } \mathrm{m}^{2}\right)\end{array}$ \\
\hline Urban/Built-up & 7813.4 & $10,006.7$ & $24,503.7$ & 2193.3 & $14,497.0$ & 16690.3 \\
\hline Water body & $34,100.0$ & $71,213.0$ & $34,600.0$ & $37,113.0$ & $-36,613.0$ & 500.0 \\
\hline Forest cover & $148,212.2$ & $172,383.2$ & $153,364.0$ & $24,171.1$ & $-19,019.3$ & 5151.8 \\
\hline Cultivated land & $226,700.0$ & $185,943.1$ & $150,677.3$ & $-40,756.9$ & $-35,265.8$ & $-76,022.7$ \\
\hline Floodplain & $23,067.1$ & 8792.8 & $39,212.7$ & $-14,274.3$ & $30,419.8$ & $16,145.5$ \\
\hline Open field & $123,231.3$ & $114,785.2$ & $160,766.4$ & -8446.1 & $45,981.2$ & $37,535.1$ \\
\hline Total & $563,124.0$ & $563,124.0$ & $563,124.0$ & & & \\
\hline \multirow{2}{*}{ Fields } & $\begin{array}{l}\text { Land cover } \\
\text { (2004) }\end{array}$ & $\begin{array}{l}\text { Land cover } \\
\text { (2013) }\end{array}$ & $\begin{array}{l}\text { Land cover } \\
\text { (2021) }\end{array}$ & \multicolumn{3}{|c|}{ LULC change (2004-2021) } \\
\hline & Area in $\%$ & Area in $\%$ & Area in $\%$ & $\begin{array}{l}\text { 2004-2013 } \\
\text { (in \%) }\end{array}$ & $\begin{array}{l}2013-2021 \\
\text { (in \%) }\end{array}$ & $\begin{array}{l}\text { 2004-2021 } \\
\text { (in \%) }\end{array}$ \\
\hline Urban/Built-up & 1.4 & 1.8 & 4.4 & +28.1 & +144.9 & +213.6 \\
\hline Water body & 6.1 & 12.6 & 6.1 & +108.8 & -51.4 & +1.5 \\
\hline Forest cover & 26.3 & 30.6 & 27.2 & +16.3 & -11.0 & +3.5 \\
\hline Cultivated land & 40.3 & 33.0 & 26.8 & -18.0 & -19.0 & -33.5 \\
\hline Floodplain & 4.1 & 1.6 & 7.0 & -61.9 & +346.0 & +70.0 \\
\hline Open field & 21.9 & 20.4 & 28.5 & -6.9 & +40.1 & +30.5 \\
\hline Total & 100 & 100 & 100 & & & \\
\hline
\end{tabular}


Table 8c: Land-use and land-cover change (LULCC) of Masina Bagar, Upallo Gosti and Tallo Gosti between 2004 and 2021.

\begin{tabular}{|c|c|c|c|c|c|c|}
\hline \multicolumn{7}{|c|}{ Masina Bagar, Upallo Gosti and Tallo Gosti } \\
\hline \multirow{2}{*}{ Fields } & \multirow{2}{*}{$\begin{array}{c}\text { Land cover } \\
(2004)\end{array}$} & \multirow{2}{*}{$\begin{array}{l}\text { Land cover } \\
(2013)\end{array}$} & \multirow{2}{*}{$\begin{array}{l}\text { Land cover } \\
\text { (2021) } \\
\text { Area in } \mathrm{m}^{2}\end{array}$} & \multicolumn{3}{|c|}{ LULC change (2004-2021) } \\
\hline & & & & $\begin{array}{l}2004-2013 \\
\quad\left(\text { in } \text { m }^{2}\right)\end{array}$ & $\begin{array}{l}2013-2021 \\
\quad\left(\text { in }^{2}\right)\end{array}$ & $\begin{array}{l}\text { 2004-2021 } \\
\quad\left(\text { in } \mathrm{m}^{2}\right)\end{array}$ \\
\hline Urban/Built-up & $32,182.5$ & $68,344.5$ & $149,092.2$ & $36,162.0$ & $80,747.8$ & $116,909.7$ \\
\hline Water body & $25,200.0$ & $37,300.0$ & $19,500.0$ & $12,100.0$ & $-17,800.0$ & -5700.0 \\
\hline Forest cover & $49,066.1$ & $40,827.9$ & $80,703.2$ & -8238.2 & $39,875.3$ & $31,637.1$ \\
\hline Cultivated land & $119,204.2$ & $79,704.8$ & 4442.4 & $-39,499.4$ & $-75,262.4$ & $-114,761.8$ \\
\hline Floodplain & $64,221.7$ & $43,245.7$ & $43,608.7$ & $-20,976.1$ & 363.0 & $-20,613.0$ \\
\hline Open field & $106,063.4$ & $126,515.1$ & $98,591.4$ & $20,451.8$ & $-27,923.8$ & -7472.0 \\
\hline Total & $395,937.9$ & $395,937.9$ & $395,937.9$ & & & \\
\hline \multirow{2}{*}{ Fields } & $\begin{array}{l}\text { Land cover } \\
\text { (2004) }\end{array}$ & $\begin{array}{l}\text { Land cover } \\
\text { (2013) }\end{array}$ & $\begin{array}{l}\text { Land cover } \\
\text { (2021) }\end{array}$ & \multicolumn{3}{|c|}{ LULC change (2004-2021) } \\
\hline & Area in $\%$ & Area in $\%$ & Area in $\%$ & $\begin{array}{c}\text { 2004-2013 } \\
\text { (in \%) }\end{array}$ & $\begin{array}{l}\text { 2013-2021 } \\
\text { (in \%) }\end{array}$ & $\begin{array}{l}\text { 2004-2021 } \\
\text { (in \%) }\end{array}$ \\
\hline Urban/Built-up & 8.1 & 17.3 & 37.7 & +112.4 & +118.1 & +363.3 \\
\hline Water body & 6.4 & 9.4 & 4.9 & +48.0 & -47.7 & -22.6 \\
\hline Forest cover & 12.4 & 10.3 & 20.4 & -16.8 & +97.7 & +64.5 \\
\hline Cultivated land & 30.1 & 20.1 & 1.1 & -33.1 & -94.4 & -96.3 \\
\hline Floodplain & 16.2 & 10.9 & 11.0 & -32.7 & +0.8 & -32.1 \\
\hline Open field & 26.8 & 32.0 & 24.9 & +19.3 & -22.1 & -7.0 \\
\hline Total & 100 & 100 & 100 & & & \\
\hline
\end{tabular}

Table 8d: Land-use and land-cover change (LULCC) of Kaseri Bazzar and Shanti Tole between 2004 and 2021.

\begin{tabular}{|c|c|c|c|c|c|c|}
\hline \multicolumn{7}{|c|}{ Kaseri Bazzar and Shanti Tole } \\
\hline \multirow{2}{*}{ Fields } & \multirow{2}{*}{$\begin{array}{l}\text { Land cover } \\
\qquad(2004) \\
\text { Area in } \mathrm{m}^{2}\end{array}$} & \multirow{2}{*}{$\begin{array}{l}\text { Land cover } \\
(2013) \\
\text { Area in } \mathrm{m}^{2}\end{array}$} & \multirow{2}{*}{$\begin{array}{l}\text { Land cover } \\
\qquad(2021) \\
\text { Area in } \mathrm{m}^{2}\end{array}$} & \multicolumn{3}{|c|}{ LULC change (2004-2021) } \\
\hline & & & & $\begin{array}{l}2004-2013 \\
\quad\left(\text { in }^{2}\right)\end{array}$ & $\begin{array}{l}2013-2021 \\
\quad\left(\text { in }^{2}\right)\end{array}$ & $\begin{array}{l}2004-2021 \\
\left(\text { in }^{2}\right)\end{array}$ \\
\hline Urban/Built-up & $49,936.4$ & $112,455.6$ & $186,736.8$ & $62,519.2$ & $74,281.2$ & $136,800.4$ \\
\hline Water body & $38,075.0$ & $30,198.6$ & $23,455.1$ & -7876.4 & -6743.4 & $-14,619.9$ \\
\hline Forest cover & $85,251.8$ & $75,264.8$ & $80,789.6$ & -9987.0 & 5524.8 & -4462.2 \\
\hline Open field & $142,807.9$ & $134,566.8$ & $60,236.7$ & $-15,333.2$ & $-74,330.1$ & $-89,663.3$ \\
\hline Floodplain & $71,808.4$ & $41,600.4$ & $42,941.1$ & $-30,208.1$ & $1,340.7$ & $-28,867.3$ \\
\hline Debris fan & 8058.4 & 8943.9 & 8870.7 & 885.5 & -73.2 & 812.3 \\
\hline Total & $403,030.1$ & $403,030.1$ & $403,030.1$ & & & \\
\hline \multirow{2}{*}{ Fields } & $\begin{array}{c}\text { Land cover } \\
(2004)\end{array}$ & $\begin{array}{l}\text { Land cover } \\
\text { (2013) }\end{array}$ & $\begin{array}{c}\text { Land cover } \\
(2021)\end{array}$ & \multicolumn{3}{|c|}{ LULC change (2004-2021) } \\
\hline & Area in $\%$ & Area in \% & Area in \% & $\begin{array}{c}2004-2013 \\
\text { (in \%) }\end{array}$ & $\begin{array}{c}2013-2021 \\
\text { (in \%) }\end{array}$ & $\begin{array}{l}\text { 2004-2021 } \\
\text { (in \%) }\end{array}$ \\
\hline Urban/Built-up & 12.4 & 27.9 & 46.3 & +125.2 & +66.1 & +273.9 \\
\hline Water body & 9.4 & 7.5 & 5.8 & -20.7 & -22.3 & -38.4 \\
\hline Forest cover & 21.2 & 18.7 & 20.0 & -11.7 & +7.3 & -5.2 \\
\hline Open field & 37.2 & 33.4 & 14.9 & -10.7 & -55.2 & -62.8 \\
\hline Floodplain & 17.8 & 10.3 & 10.7 & -42.1 & +3.2 & -40.2 \\
\hline Debris fan & 2.0 & 2.2 & 2.2 & +11.0 & -0.8 & +10.1 \\
\hline Total & 100 & 100 & 100 & & & \\
\hline
\end{tabular}


Table 9: Hydro-torrential hazard prone areas in the Seti valley: Sabche Cirque - Pokhara City (Location No. are given in Fig. 1. No. 6 is missing because there is presently no settlement or infrastructure at this place).

\begin{tabular}{|c|c|c|}
\hline Location No. & Potential hazard & Remarks \\
\hline 1. Outlet of Sabche Cirque & $\begin{array}{l}\text { Susceptible to river blockage and damming due } \\
\text { to the deep and narrow gorge. }\end{array}$ & \\
\hline 2. Jimirbaari & $\begin{array}{l}\text { Susceptible to flooding (Seti flood) and } \\
\text { damming due to landslides from river-bank } \\
\text { slopes. }\end{array}$ & $\begin{array}{l}\text { Intake of the upper Seti hydropower project ( } 25 \mathrm{MW} \text { ) } \\
\text { is being built in the floodplain. }\end{array}$ \\
\hline 3. Saadal and Ebang & $\begin{array}{l}\text { Susceptible to flooding (Seti flood) and } \\
\text { damming due to the bottleneck channel and } \\
\text { landslides from left bank. }\end{array}$ & $13 \mathrm{HHs}$ are living in the floodplain. \\
\hline 4. Bharabhuri Bagar & Susceptible to flooding (Seti flood). & $\begin{array}{l}\text { Power house of the upper Seti hydropower project } \\
(25 \mathrm{MW}) \text { and intake of the middle Seti hydropower } \\
\text { project ( } 24 \mathrm{MW}) \text { are being built in the floodplain. }\end{array}$ \\
\hline $\begin{array}{l}\text { 5. Khaarpaani Tatopani } \\
\text { (natural hot-spring site) }\end{array}$ & Susceptible to flooding (Seti flood). & $\begin{array}{l}\text { Bridge, road and headrace of hydropower have been } \\
\text { built in the floodplain. }\end{array}$ \\
\hline $\begin{array}{l}\text { 7. Mardi Dovan (confluence } \\
\text { of Mardi River and Seti } \\
\text { River) }\end{array}$ & $\begin{array}{l}\text { Susceptible to flooding (Seti flood and Mardi } \\
\text { flood) and landslides from right bank of Seti } \\
\text { River downstream the confluence. }\end{array}$ & $\begin{array}{l}\text { A steel truss bridge is built in the floodplain carrying } \\
\text { drinking water main pipes for Pokhara city. Similarly, } \\
\text { drinking water pipes (for Pokhara city) are laid in the } \\
\text { floodplain along the left bank of the Seti River. A } \\
60 \text {-m long road bridge is also built in the floodplain } \\
\text { with insufficient freeboard. }\end{array}$ \\
\hline 8. Hemja Bensi Bridge site & Susceptible to river-bank erosion and incision. & $\begin{array}{l}\text { The bridge is used for crossing the water pipe for } \\
\text { Pokhara city and was built after the previous bridge } \\
\text { was washed-way by the May } 2012 \text { Seti flood. }\end{array}$ \\
\hline $\begin{array}{l}\text { 9. Masina Bagar, Upallo } \\
\text { Gosti and Tallo Gosti }\end{array}$ & $\begin{array}{l}\text { Susceptible to flooding (Seti flood), bank } \\
\text { erosion and edge falls along right bank of the } \\
\text { Seti flow. }\end{array}$ & $\begin{array}{l}\text { About } 102 \text { households as slum settlement are residing } \\
\text { in the floodplain. }\end{array}$ \\
\hline $\begin{array}{l}\text { 10. Kaseri (Laltin) Bazzar } \\
\text { and Shanti Tole }\end{array}$ & $\begin{array}{l}\text { Susceptible to flooding (Seti flood) and bank } \\
\text { erosion in both banks. }\end{array}$ & $\begin{array}{l}\text { About } 220 \text { households in Kaseri and } 180 \text { househlods } \\
\text { in Shanti Tole are residing in the floodplain. }\end{array}$ \\
\hline $\begin{array}{l}\text { 11. Sukhawati Gumba and } \\
\text { KI Singh Bridge }\end{array}$ & $\begin{array}{l}\text { Susceptible to flooding (Seti flood) and } \\
\text { damming due to the bottleneck channel at KI } \\
\text { Singh bridge and block falls from the river } \\
\text { banks. }\end{array}$ & The Gumba (Monastery) is built in the floodplain. \\
\hline 12. Narayanthan & $\begin{array}{l}\text { Susceptible to flooding (Seti flood) and } \\
\text { damming due to the bottleneck channel at } \\
\text { Narayanthan bridge and occasional bank } \\
\text { toppling. }\end{array}$ & \\
\hline 13. Ramghat & $\begin{array}{l}\text { Susceptible to river blockage and damming due } \\
\text { to the bottleneck channel at its outlet and edge } \\
\text { falls (bank toppling). }\end{array}$ & $\begin{array}{l}\text { Ramghat depression often gets inundated once or } \\
\text { twice a year every monsoon season. This situation } \\
\text { may turn into the disaster if the flow is blocked by } \\
\text { river-bank topples downstream the Ramghat or if } \\
\text { another flash flood occurs during monsoon. }\end{array}$ \\
\hline $\begin{array}{l}\text { 13-14. Seti gorge section } \\
\text { from Prithvi highway bridge } \\
\text { (China bridge) to Ratopahiro }\end{array}$ & Susceptible to river incision, and edge falls. & $\begin{array}{l}\text { The Seti banks are severly cracked on the ground and } \\
\text { at some places, the large blocks are hanging on the } \\
\text { top of the river bank. These blocks may fall down or } \\
\text { bank toppling may take place at any time due to the } \\
\text { continuous river erosion or under the influence of a } \\
\text { strong earthquake, hence might block the Seti flow } \\
\text { causing unwanted disaster. }\end{array}$ \\
\hline
\end{tabular}

\section{DISCUSSION}

\section{Fluvial Risk Management through the concept of good functionment's space}

Though very expensive structural measures were applied for the control and management of fluvial risk, past flood events around the world have proven that no structural protection measures against floods are absolute (Pottier et al., 2005). Indeed, the fluvial risk management through the "functional flooding space or freedom space concept for river" is considered to be the best way for the sustainable management of floods (Piégay et al., 2005; Arnaud-Fassetta et al., 2009; Kondolf, 2011). Providing more space for rivers to migrate and flood naturally without any danger appears to be the obvious approach for the sustainable management of fluvial risk, because this approach of river management is not only "environmentally 
friendly" but is also economically sensible and it can save human lives in heavily populated alluvial plains. In fact, any structural control measures built within the freedom space of river could be repeatedly affected during floods. The "functional flooding area" should be maintained along the river at the entire catchment scale to ensure safety from the risk of future floods. From an operational point of view, giving more space to rivers is achieved by limiting the actions that interfere with the processes of flooding, erosion, and sediment transport and by avoiding addition of vulnerabilities in the space subject to hazards. In the case of the Seti River, the examples chosen could not bring out any differences between the theoretical width of the active channel (step ii), the historical space of the river (step iii) and the maximum flooding area (step i) for two reasons: no "large" event could be documented (i.e., mapped) between the Middle Ages and 2012, and the selected areas are fairly confined so that there is no actual floodplain development (Fig. 11 and Fig. 12)

\section{Why are people living in potential flood hazard areas?}

Short-term economic benefits (or livelihood) were found to be the main reason for living in those potential flood-hazard areas: for example, people earn money by extracting sand, boulder and aggregate from the river. After the 2012 Seti flood, locals of Saadal and Ebang were relocated to Sano Khobang (a safer Saadal and Ebang) by the Nepal Government. But since people could not find any means of livelihood in the new area, after a few months of living, they returned to the same old place and ever since are living in the floodplain. The other reasons for people to live on risky areas are (i) failure to implement the land use rule by the state authorities and (ii) lack of public awareness about the possible floods.

\section{What role is sand mining playing?}

Sand and gravel mining practices are causing increase of natural hazards and degradation of environment such as destruction of aquatic lives and habitat (Fort et al., 2018). More importantly, they lead to bank failure by deepening of river bed. Actually sands are often extracted from river banks because in most cases, there is not access to middle part of the river due to flow. This sand mining process makes the riverbed close to the bank deeper than the middle part of the river bed so that during monsoon time, major river flow tends to concentrate along river banks, eroding them, hence causing bank failure, thus leading to an increase of river width. Sand and gravel mining reduce boulders that obstruct flow in river, thus help increase the velocity of flow and increase river erosion process. This ultimately causes deepening of the river. In the long term, sand mining creates permanent loss of sand since sands are eventually formed after friction between different boulders on the course of its flow in the river system. If there are less boulders in the river, that means enough friction will not take place, which will reduce production of sand in rivers. Furthermore, indiscriminate sand mining causes the frequent and unpredictable shifting of river channels and riverbank incision. Every year, the Pokhara Metropolitan city makes earnings of US\$ 4.5 million (Pokhara Metropolitan Annual Report, 2019) from the revenue of sand mining of the Seti River within its boundary. Though sand mining is creating the above-mentioned problems, short economic benefits seem to outweigh those problems. In long-term, this is not a healthy practice. This does not mean that sand mining should be stopped forever and for all places. The focus should be on the practice of sustainable sand mining. Sand and gravel mining in rivers would be sustainable if the quantity of material extracted is within the volume 'replenished' by the river system, and if sufficient sand and gravel remains in the system to maintain downstream river beds, deltas and coastal natural environments.

\section{Government's Apathy}

From this study, the main anthropogenic interventions along the Seti River that affect flooding seemed to be river encroachment (narrowing of riverbeds in floodplain areas) in the name of infrastructure development and slum settlement. It has been more than eight years since the devastating floods occurred in the Seti River but the conditions along the river are as they were and even getting worser than ever before. This does seem so mainly due to the government's apathy. Instead of relocating people from the vulnerable slum settlements to safer places, the government and local authorities rather seem to have encouraged people to live in the floodplain by providing basic amenities such as drinking water, electricity and access road. Public authorities are not taking any action against possible disasters since local politics seem to outweigh the proper land use planning and building codes. Sadly, these squatter settlements are being used as vote bank by politicians and political parties for many years and instead of managing such vulnerable settlements to safer places, these squatter settlements have been given land owner certificates, thus letting people to live in the riverbanks and flood plains permanently.

\section{Is another flood to the scale of May 5, 2012 or even greater possible in the Seti River?}

This is a crucial question, which answers are clearly depending on two drivers. (i) In a context of climate change (Bajracharya et al. 2018), the processes that have triggered the May 5, 2012 rock-falls and avalanche in Sabche Cirque can be repeated again. 
During the winter season, the Sabche depression and surrounding mountains are heavily covered by snow and ice, and that can bring more avalanches during summer. Increased freeze-thaw cycles of permafrost due to temperature warming (rather than increased freeze-thaw cycle due to climate change, it has increased the thawing depth) is an additional trigger for mountain walls collapses (Deline et al., 2015). Since the Seti gorge (the entrance from Sabche Cirque) is too narrow and deep, it is unusually prone to dangerous blockages following such rock falls and avalanches; if the blockage in the Seti gorge bursts, there is a potential to produce other destructive floods downstream. The recent Chamoli, Uttarkhand (India) disastrous debris flow event that occurred on 7th February 2021 which took more than 200 lives and destroyed many infrastructure projects worth billion dollars, is quite similar to the 2012 Seti flood (hyperconcentrated flow event): actually, this Chamoli debris flow was also triggered by a massive rockslide (Petley, 2021; Shrestha et al., 2021; Shugar et al., 2021). So, all these pose a strong probability of recurring high floods in the Seti River. Furthermore, since the Seti valley receives the highest rainfall in Nepal and flows through the bottleneck channels and highly unstable bank slopes, these areas are prone to landslide dams, and hence can produce landslide dam outburst floods (LDOF). (ii) As we better know now, the Sabche Cirque was also the source for past mega debris-flow events (AD 1100, 1255, and 1344) triggered by mega earthquakes that formed the overall landscape of Pokhara valley (Fort, 1987, 2010; Schwanghart et al., 2016; Stolle et al., 2017). Actually, the Pokhara valley and the Seti catchment lie in a high-seismic gap zone and scientists have warned that a major earthquake may hit this region at any time (Bollinger et al., 2016; Bilham, 2019) that could generate a giant, very destructive debris flow again at the valley scale. To sum up, anthropogenic activities (infrastructure, settlements) on the riverbed and flood plains should be avoided. If bridges are to be constructed, these should be built outside the freedom space of river and their freeboard should be sufficient to allow the extreme flood discharges. Further, nonstructural measures such as flood forecasting, early warning system, public awareness, emergency plans, strict land-use regulations and policies help manage fluvial risk. This is especially true if the government, community and the local people work together to this end.

\section{CONCLUSIONS}

The Seti valley is as beautiful as it is dangerous. There is a high possibility of similar flash floods to the scale of 2012 or greater in Seti River given the hydro-geomorphological context, climate change and seismic gap. As rivers change their course within their own floodway after a certain period of time, they may retrace their old course within the floodway, therefore the flood plains need to be left unaltered and anthropogenic activities should be avoided from floodplains. As discussed above, the "river functional flooding space or freedom space" concept for river should be applied for the sustainable management of fluvial risk. Moving away from vulnerable areas will reduce the likelihood of disasters. Unless the vulnerable settlements are relocated, any amount of investment for the structural protection work will not lead to a sustainable solution. Further, a good early warning system should be set up. Active geological process and associated geo-hazards (such as rock falls, landslides, avalanches in the catchment), regular hydro-meteorological events, haphazard settlements and construction of infrastructure projects and presence of deep and narrow gorges appear as persistent drivers to aggravate flooding in the Seti valley increasing fluvial risks. Climate change impact is adding more on it like the May 5, 2012 rock-falls and avalanche event in Sabche Cirque (Bajracharya et al. 2018) that had taken place in dry time. Over a dozen settlements have sprung up on the Seti banks and along the old course of the Seti River, and construction activities are still continuing at a frenzied pace, often encroaching flood spaces. All in all, anthropogenic activities are responsible to transform active, natural hazards into disasters. The best way to deal with the possible flooding is not to build any infrastructure or dwellings on the floodplain but implement strict land-use policy, have an effective early warning system in place, monitor rivers regularly for blockages especially after earthquakes or landslides, relocate riverside settlements to safer places and discourage settlements directly beside rivers.

\section{ACKNOWLEDGEMENTS}

The authors would like to thank University of Paris, UMR 8586 PRODIG, France, and Kadoorie Agricultural Aid Association, Nepal. This paper is a contribution to the SarDYN Project "Natural dynamics, infrastructure construction and tourism economy in the context of a developing country: Nepal (Central Himalaya)" granted by the LABEX DYNAMITE. The authors are grateful to Simrik Air Pvt. Ltd. For their help to conduct aerial survey in Sabche Cirque. Finally, the authors are also thankful to local people of Shanti Bazzar, Kaseri Bazzar, Upallo Gosti, Karuwa, Kapuche, Ebang and Saadal for their help and interaction during the study. Comments by three anonymous reviewers helped improving the clarity of the manuscript.

\section{AUTHOR'S CONTRIBUTIONS}

N. Gurung, M. Fort and G. Arnaud-Fassetta proposed 
the current study as part of the Ph.D. research work of the first author N. Gurung. M. Fort, G. ArnaudFassetta assisted N. Gurung during the field work. N. Gurung wrote the paper and prepared figures with assistance from M. Fort, G. Arnaud-Fassetta and R. Bell. N. Maharjan joined N. Gurung for the analysis and preparation of LULC maps. All authors discussed, reviewed and finalized the paper.

\section{REFERENCES}

Adger, W.N., Benjaminsen, T.A., Brown, K., and Svarstad, H., 2001, Advancing a political ecology of global environmental discourse. Development and Change, $32,681-715$.

Alexander, D., 2000, Confronting catastrophe: new perspectives on natural disasters. Oxford University Press, New York, 288 p.

Arcement, G.J. and Schneider, V.R., 1989, Guide for selecting Manning's roughness coefficients for natural channels and flood plains. United States Geological Survey Water-Supply Paper 2339, https:// pubs.usgs.gov/wsp/2339/report.pdf.

Arnaud-Fassetta, G. and Fort, M., 2009, The integration of space of good functionment in fluvial geomorphology, as a tool for mitigating flood risk. Application to the left-bank tributaries of the Aude River, Mediterranean France. In (Gumiero B., Rinaldi M., Fokkens B. Eds.) Ivth ECRR International Conference on River Restoration 2008, Centro Italiano per la Riqualificazione Fluviale, 313-322.

Arnaud-Fassetta, G., Astrade, L., Bardou, É., Corbonnois, J., Delahaye, D., Fort, M., Gautier, E., Jacob, N., Peiry, J., Piégay, H., and Penven, M. J., 2009, Fluvial geomorphology and flood-risk management. Geomorphology: Relief, Processus, Environment, $15,109-128$,

DOI: https://DOI.org/10.4000/geomorphologie.7554.

Bajracharya, A.R., Bajracharya, S.R., Shrestha, A.B., and Maharjan, S.B., 2018, Climate change impact assessment on the hydrological regime of the Kali Gandaki Basin, Nepal. Science of the Total Environment, 625, p. 837-848. DOI: https://doi. org/10.1016/j.scitotenv.2017.12.332

Bardou, É., Fournier, F., and Sartori, M., 2003, Palaeoflood reconstruction at Illgraben torrent (Switzerland): a current need for event frequency estimation. In: Thorndycraft, V.R., Benito, G., Barriendos, M., Llasat, M.C. (Eds.): Palaeofloods, Historical Floods and Climatic Variability: Applications in Flood Risk Assessment. Proceedings of the International workshop on palaeoflood and historical evidence in flood risk assessment, Barcelona, 16-19 October 2002, 53-59.

Basnet, K., and Acharya, D., 2019, Flood Analysis at Ramghat, Pokhara, Nepal Using HEC-RAS, Technical Journal 1, 1, 41-53. DOI: 10.3126/ tj.v1i1.27591.
Bhandary, N.P., Dahal, R. K., and Okamura, M., 2012. Preliminary understanding of the Seti River Debrisflood in Pokhara, Nepal on May 5th, 2012. ISSMGE Bulletin, 6:4, 83-89. Accessible on: http://www. ranjan.net.np/journal_papers/setiIssmg.pdf

Bilham, R., 2019, Himalayan earthquakes: a review of historical seismicity and early 21 st century slip potential. Geological Society, London, Special Publications, 483. DOI: https://DOI.org/10.1144/ SP483.16.

Bollinger, L., Sapkota, S.N., Tapponnier, P., and Klinger, Y., 2016, Slip deficit in central Nepal: omen for a repeat of the $1344 \mathrm{AD}$ earthquake? Earth, Planets and Space, 68, 12. DOI:10.1186/s40623-016-0389-1.

Burbank, D.W., Blythe, A.E., Putkonen, J.K., Pratt-Situala, B.A., Gabet, E.J., Oskin, M.E., Barros, A.P., and Ohja, T.P., 2003, Decoupling of erosion and climate in the Himalaya. Nature, 426, 6967, 652-655.

Colchen, M., Le Fort, P., and Pêcher, A., 1981, Geological map of Annapurnas-Manaslu-Ganesh Himalaya of Nepal. In: Gupta, H.K., Delany, F.M. (Eds): ZagrosHindu Kush, Himalayas: Geodynamic Evolution. American Geophysical Union, Washington D.C. (scale 1: 200,000).

Deline, P., Gruber, S., Delaloye, R., Fischer, L., Geertsema, M., Giardino, M., Hasler, A., Kirkbride, M., Krautblatter, M., Magnin, F., McColl, S., Ravanel, L., and Schoeneich, P., 2015, Chapter 15 - Ice Loss and Slope Stability in High-Mountain Regions, In: Shroder, J.F., Haeberli, W., Whiteman, C. (Eds.), Snow and Ice-Related Hazards, Risks and Disasters. Academic Press, Boston, 521-561.

DHM - Government of Nepal, Ministry of Energy, Water Resources and Irrigation, Department of Hydrology and Meteorology (DHM). http://www.dhm.gov.np/.

DHM - Government of Nepal, Ministry of Energy, Water Resources and Irrigation, Department of Hydrology and Meteorology (DHM). http://dhm.gov.np/ meteorological-station/.

Dwivedi, S. and Neupane, Y. 2013, Cause and mechanism of the Seti River flood, 5th May 2012, western Nepal. Journal of Nepal Geological Society, 46, 11-18.

Fort, M., 1986, Glacial extension and catastrophic dynamics along the Annapurna front, Nepal Himalaya. Sonderdruk Aus, Göttinger Geographische Abhandlungen, 81, 105-125.

Fort, M., 1987, Sporadic morphogenesis in a continental subduction setting: An example from the Annapurna Range, Nepal Himalaya. Zeitschrift für Geomorphologie, Suppl. Bd., 63, 9-36.

Fort, M., 2010, The Pokhara valley: A product of a natural catastrophe. In: Migon, P. (Ed.), Geomorphological Landscapes of the World. Springer, Dordrecht, The Netherlands, 265-274.

Fort, M. and Freytet, P., 1983, The Quaternary sedimentary evolution of the intramontane basin of Pokhara, in relation to the Himalayan Midlands and their 
hinterland (West Central Nepal). In: Sinha, A.K. (Ed.) Contemporary Geoscientific Research in Himalaya, vol.2, Publ. Bishen Singh Mahendra Pal Singh, Dehradun, India. 91-96.

Fort, M., Adhikari, B.R., and Rimal, B., 2018, Pokhara (Central Nepal): A Dramatic, Yet Geomorphologically Active Environment Versus a Dynamic, Rapidly Developing City. In: Thornbush, M.J. and Allen C.D. (Eds) Urban Geomorphology: Landforms and Processes in Cities, Ch. 12. Elsevier S\&T Books, 231-258.

Gabet, E.J., Burbank, D.W., Putkonen, J.K., Pratt-Sitaula, B.A., and Ojha, T.P., 2004, Rainfall thresholds for landsliding in the Himalayas of Nepal. Geomorphology 63, 131-143.

Gill , J. C. and Malamud, B. D., 2017, Anthropogenic processes, natural hazards, and interactions in a multi -hazard framework. Earth-Science Reviews, 166, 246-269. DOI:10.1016/j.earscirev.2017.01.002

Gurung, H.B., 1965, Pokhara Valley, Nepal Himalaya. A field study in Regional Geography. Unpublished PhD thesis, University of Edinburgh, 246 p.

Gurung, H.B., 1970, Geomorphology of Pokhara Valley. Himalayan Review, 2-3, 29 - 49.

Gurung, N., Fort, M., Arnaud-Fassetta, G., Bell, R., and Sherchan, B., 2020, Construction of road bridges without consideration of geo-hazards and riverflow dynamics. A case study from Ghatte Khola, Myagdi, Nepal. Géomorphologie: Relief, Processus, Environnement, 26 (3), p. 195 - 215. DOI: 10.4000/ geomorphologie. 14777

Hanisch, J. and Koirala, A., 2010, Pokhara Valley: a place under permanent threat? Abstract, Journal of Nepal Geological Society, 41, 119.

Hanisch, J., Koirala, A., and Bhandary, N.P., 2013, The Pokhara May 5th flood disaster: A last warning sign sent by nature? Journal of Nepal Geological Society, 46, 1-10.

HEC-RAS 5.0, 2016, Hydraulic reference manual, version 5. US Army Corps of Engineers.

Hormann, K., 1974, Die Terrassen an der Seti Khola: Ein Beitrag zur quartären Morphogenese in Zentralnepal. Erdkunde, 28, 3, 161-176.

Jha, P.C., 1996, Maximum rainfall discharge for the design of road structures of Nepal, Technical University, Moscow, Russia.

Kargel, J., Paudel, L., Leonard, G., Regmi, D., Joshi, S., Poudel, K., Thapa, B., Watanabe, T., and Fort, M., 2013, Causes and Human Impacts of the Seti River (Nepal) Disaster of 2012. Proc. Glacial Flooding and Disaster Risk Management, Knowledge Exchange and Field Training, July 11-24, 2013 in Huaraz, Peru.

Kargel, J., Leonard, G., Paudel, L., Regmi, D., Bajracharya, S., Fort, M., Poudel, K., Joshi, S., Poudel, K., Thapa, B., and Watanabe, T., 2014, Seti River flood disaster and alpine cryospheric hazards facing Pokhara, Nepal.
Geophysical Research Abstracts, 16, EGU201412448-2. EGU General Assembly 2014.

Kline, M., and Cahoon, B., 2010, Protecting river corridors in Vermont. Journal of the American Water Resources Association, 46, 2, 227-236.

Koirala, A. and Rimal, L.N., 1996, Geological hazards in Pokhara Valley, western Nepal. Journal of Nepal Geological Society, 13, 99 -108.

Koirala, A.,1998, Report on engineering and environmental geological map of Pokhara valley. Department of Mines and Geology, Kathmandu, Nepal, 1-20.

Koirala, A., Rimal, L.N., Sikrikar, S.M., Pradhananga, U.B., and Pradhan, P.M., 1998, Engineering and environmental geological map of Pokhara Valley, scale 1:50000.

Koirala, A., Hanisch, J., and Geyh, M.A., 1998, Recurrence history of debris flow events in Pokhara valley: a preview. Proceedings volume of Nepal Geological Society, 16, 93-94.

Kondolf, G.M., and Piégay, H., 2003, Tools in fluvial geomorphology. Wiley, Chichester, 688 p. DOI: 1002/0470868333.

Kuichling, E.,1889, The relation between the rainfall and the discharge of sewers in populous areas. Transactions of the American Society of Civil Engineers, 20, 1-56.

Malavoi, J.-R., Bravard, J.-P., Piégay, H., Héroin, E. and Ramez, P., 1998, Détermination de l'espace de liberté des cours d'eau. Guide Technique n², Bassin Rhône Méditerranée Corse, DIREN Rhône-Alpes, 40 p.

Mulvaney, T.J., 1851, On the use of self-registering rain and flood gauges in making observations of the relations of rainfall and flood discharges in a given catchment. Proceedings of the Institution of Civil Engineers of Ireland, 4, 19-31.

NASA, Earth Observatory, 2013, Making Sense of Nepal's Seti River Disaster.

https://earthobservatory.nasa.gov/images/82937/ making-sense-of-nepals-seti-river-disaster

Oi, H., Higaki, D., Yagi, H., Usuki, N., and Yoshino, K., 2014, Report of the investigation of the flood disaster that occurred on May 5, 2012 along the Seti River in Nepal, International Journal of Erosion Control Engineering, 7, 4, 111- 117.

Ollero, A., 2010, Channel changes and floodplain management in the meandering middle Ebro River, Spain. Geomorphology, 117, 247-260.

Petley, D. and Stark, C.P., 2012, Understanding the Seti River landslide in Nepal.

http://blogs.agu.org/landslideblog/2012/05/23/ understanding-the-seti-river-landslide-in-nepal/.

Petley, D., 2014, The Seti River landslide disaster in Nepal: two years on. The Landslide Blog - AGU Blogosphere,30.04.2014.https://blogs.agu.org/ landslideblog/2014/04/30/the-seti-river-landslide-2/. 
Petley, D., 2021, The catastrophic landslide and flood in Chamoli in Uttarakhand: the sequence of events. The Landslide Blog AGU Blogosphere, 08.02.2021,

https://blogs.agu.org/landslideblog/2021/02/08/chamoli-2/

Petley, D., 2021, High resolution Planet Labs imagery of the Chamoli landslide in Uttarakhand. 11.02.2021. https://blogs.agu.org/landslideblog/2021/02/11/ chamoli-landslide-3/.

Piégay, H., Darby, S. E., Mosselman, E., and Surian, N., 2005, A review of techniques available for delimiting the erodible river corridor: a sustainable approach to managing bank erosion. River Research and Applications, 21(7), 773-789. DOI:10.1002/rra.881

Pokhara Metropolitan Annual Report, 2019, Annual Progress Report published by Pokhara Metropolitan Office, August, 2020.

Pottier, N., Penning-Rowsell, E., Tunstall, S., and Hubert, G., 2005, Land use and flood protection: contrasting approaches and outcomes in France and in England and Wales. Appl Geogr. 25:127

Rijal, K.P., 2014, Comparative study of flood calculation approaches, a case study of East Rapti River Basin, Nepal. Hydro Nepal: Journal of Water, Energy and Environment, 15, 60-64.

Rimal, B., Baral, H., Stork, N., Paudyal, K., and Rijal, S., 2015, Growing city and rapid land use transition: assessing multiple hazards and risks in the Pokhara Valley, Nepal. Land 4, 4, 957-978. DOI:10.3390/ land4040957.

Schwanghart, W., Bernhardt, A., Stolle, A., Hoelzmann, P., Adhikari, B.R., Andermann, C., Tofelde, S., Merchel, S., Rugel, G., Fort, M., and Korup, O., 2016, Repeated catastrophic valley infill following medieval earthquakes in the Nepal Himalaya. Science Magazine, 351, 6269, 147-150.

Sharma, K.P. and Adhikari, N.R., 2004, Hydrological estimations in Nepal. Department of Hydrology and Meteorology, Government of Nepal, Nepal.

Shrestha, A.B., 2008, Resource manual on flash flood risk management, Module 2: Non-structural measures. International Centre for Integrated Mountain Development, Kathmandu, p. 91.

Shrestha, A.B., Steiner, J., Nepal, S., Maharjan, S.B., Jackson, M., Rasul, G., and Bajracharya, B., 2021, Understanding the Chamoli flood: Cause, process, impacts, and context of rapid infrastructure development, International Centre for Integrated Mountain Development (ICIMOD), 3 March 2021, River Basins and cryosphere.

Shugar, D.H, Jacquemart, M., Shean, D., Bhushan, S., Upadhyay, K., Sattar, A., Schwanghart, W., McBridE, S., Van Wyk de Vries, M., Mergili, M., Emmer, A., Deschamps-Berger, C., McDonnell, M., Bhambri, R., Allen, S., Berthier, E., Carrivick, J.L.,
Clague, J.J., Dokukin, M., Dunning ,S.A., Frey, H., Gascoin, S., Haritashya ,U.K., Hugge, C., Kääb, A., Kargel, J.S., Kavanaugh, J.L., Lacroix, P., Petley, D., Rupper, S., Azam, M.F., Cook, S.J., Dimri, A.P., Eriksson, M., Farinotti, D., Fiddes, J., Gnyawali, K.R., Harrison, S., Jha, M., Koppes, M., Kumar, A., Leinss, S., Majeed, U., Mal, S., Muhuri, A., Noetzli, J., Paul, F., Rashid, I., Sain, K., Steiner, J., Ugalde, F., Watson, C.S., and Westoby, M.J., 2021: A massive rock and ice avalanche caused the 2021 disaster at Chamoli, Indian Himalaya, Science, 10 June 2021, DOI: $10.1126 /$ science.abh4455

South Asia Network on Dams, Rivers and People (SANDRP), 2014, Explained: Seti River floods in May 2012, Nepal. A chain of events, starting at 25,000 feet ! https://sandrp.in/2014/01/26/explainedseti-river-floods-in-may-2012-nepal-a-chain-ofevents-starting-at-25000-feet/.

Stolle, A., Bernhardt, A., Schwanghart, W., Hoelzmann, P., Adhikari, B.R., Fort, M., and Korup, O., 2017, Catastrophic valley fills records large Himalayan earthquakes, Pokhara, Nepal, Quaternary Science Reviews, 177, 88-103.

Stolle, A., Schwanghart, W., Andermann, C., Bernhardt, A., Fort, M., Jansen, J., Wittmann, H., Merchel, S., Rugel, G., Adhikari, B.R., and Korup, O., 2019, Protracted river response to medieval earthquakes. Earth Surface Processes and Landforms, 44, 331341. DOI: 10.1002/esp.4517.

United Nations office for Disaster Risk Reduction (UNDRR), https://www.undrr.org/

Upreti, B.N. and Yoshida, M., 2005, Guidebook for Himalayan Trekkers, Series No. 1, Geology and natural hazards along the Kali Gandaki valley, Nepal. Special Publication 1, Department of Geology, Trichandra Campus, Tribhuvan University, Kathmandu, Nepal, 164 p.

USGS Earth Explorer, https://earthexplorer.usgs.gov

Waylen, K.A., Holstead, K.L., Colley, K., and Hopkins, J., 2018, Challenges to enabling and implementing natural flood management in Scotland. Journal of Flood Risk Management, 11, S1078-S1071

WECS/DHM, 1990, Methodologies for estimating hydrologic characteristics of ungauged locations in Nepal. Water and Energy Commission Secretariat and Department of Hydrology and Meteorology method.

Wester, P., Mishra, A., Mukherji, A., and Shrestha, A. B., 2019, The Hindu Kush Himalaya assessment. Mountain, Climate Change, Sustainability and People. Basel and Cham Switzerland: Springer. DOI: 10.1007/978-3-319-92288-1

Yamanaka, H., Yoshida, M., and Arita, K., 1982, Terrace Landform and Quaternary Deposit Around Pokhara Valley, Central Nepal. Journal of Nepal Geological Society, 2 (Special Issue), 95-112. 